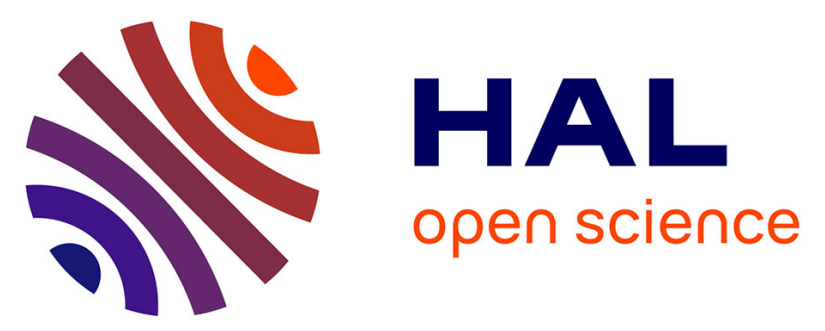

\title{
Systematic lidar observations of Saharan dust over Europe in the frame of EARLINET (2000-2002)
}

\author{
A. Papayannis, V. Amiridis, L. Mona, G. Tsaknakis, D. Balis, J. Bösenberg,
} A. Chaikovsky, F. de Tomasi, I. Grigorov, I. Mattis, et al.

\section{To cite this version:}

A. Papayannis, V. Amiridis, L. Mona, G. Tsaknakis, D. Balis, et al.. Systematic lidar observations of Saharan dust over Europe in the frame of EARLINET (2000-2002). Journal of Geophysical Research: Atmospheres, 2008, 113 (D10), pp.D10204. 10.1029/2007JD009028 . hal-00283360

\section{HAL Id: hal-00283360 https://hal.science/hal-00283360}

Submitted on 5 Feb 2016

HAL is a multi-disciplinary open access archive for the deposit and dissemination of scientific research documents, whether they are published or not. The documents may come from teaching and research institutions in France or abroad, or from public or private research centers.
L'archive ouverte pluridisciplinaire HAL, est destinée au dépôt et à la diffusion de documents scientifiques de niveau recherche, publiés ou non, émanant des établissements d'enseignement et de recherche français ou étrangers, des laboratoires publics ou privés. 


\title{
Systematic lidar observations of Saharan dust over Europe in the frame of EARLINET (2000-2002)
}

\author{
A. Papayannis, ${ }^{1}$ V. Amiridis, ${ }^{2}$ L. Mona, ${ }^{3}$ G. Tsaknakis, ${ }^{1}$ D. Balis,${ }^{4}$ J. Bösenberg, ${ }^{5}$ \\ A. Chaikovski, ${ }^{6}$ F. De Tomasi, ${ }^{7}$ I. Grigorov, ${ }^{8}$ I. Mattis, ${ }^{9}$ V. Mitev, ${ }^{10}$ D. Müller, ${ }^{9}$ \\ S. Nickovic, ${ }^{11,12}$ C. Pérez, ${ }^{13}$ A. Pietruczuk, ${ }^{14}$ G. Pisani, ${ }^{15}$ F. Ravetta, ${ }^{16}$ V. Rizi,${ }^{17}$
}

M. Sicard, ${ }^{18}$ T. Trickl, ${ }^{19}$ M. Wiegner, ${ }^{20}$ M. Gerding, ${ }^{21}$ R. E. Mamouri, ${ }^{1}$ G. D'Amico, ${ }^{3}$

and G. Pappalardo ${ }^{3}$

Received 31 May 2007; revised 27 January 2008; accepted 18 February 2008; published 29 May 2008.

[1] More than 130 observation days of the horizontal and vertical extent of Saharan dust intrusions over Europe during the period May 2000 to December 2002 were studied by means of a coordinated lidar network in the frame of the European Aerosol Research Lidar Network (EARLINET). The number of dust events was greatest in late spring, summer, and early autumn periods, mainly in southern (S) and southeastern (SE) Europe. Multiple aerosol dust layers of variable thickness $(300-7500 \mathrm{~m})$ were observed. The center of mass of these layers was located in altitudes between 850 and $8000 \mathrm{~m}$. However, the mean thickness of the dust layer typically stayed around $1500-3400 \mathrm{~m}$ and the corresponding mean center of mass ranged from 2500 to $6000 \mathrm{~m}$. In exceptional cases, dust aerosols reached northwestern (NW), northern (N), or northeastern (NE) Europe, penetrating the geographical area located between $4^{\circ} \mathrm{W}-28^{\circ} \mathrm{E}$ (longitude) and $38^{\circ} \mathrm{N}-$ $58^{\circ} \mathrm{N}$ (latitude). Mean aerosol optical depths (AOD), extinction-to-backscatter ratios (lidar ratios, LR), and linear depolarization ratios of desert aerosols ranged from 0.1 to 0.25 at the wavelength of 355 or $351 \mathrm{~nm}, 30$ to $80 \mathrm{sr}$ at 355 or $351 \mathrm{~nm}$, and 10 to $25 \%$ at $532 \mathrm{~nm}$, respectively, within the lofted dust plumes. In these plumes typical Saharan dust backscatter coefficients ranged from 0.5 to $2 \mathrm{Mm}^{-1} \mathrm{sr}^{-1}$. Southern European stations presented higher variability of the LR values and the backscatter-related Angström exponent values (BRAE) (LR: 20-100 sr; BRAE: -0.5 to 3) than northern ones (LR: $30-$ 80 sr; BRAE: -0.5 to 1$)$.

Citation: Papayannis, A., et al. (2008), Systematic lidar observations of Saharan dust over Europe in the frame of EARLINET (2000-2002), J. Geophys. Res., 113, D10204, doi:10.1029/2007JD009028.

\section{Introduction}

[2] Mineral dust is an important component of the atmospheric aerosol loading with an annual rate of about $1-2 \mathrm{Pg}$ of dust eroded by the wind from bare soils and lofted into

\footnotetext{
${ }^{1}$ Physics Department, National Technical University of Athens, Athens, Greece.

${ }^{2}$ Institute for Space Applications and Remote Sensing, National Observatory of Athens, Athens, Greece.

${ }^{3}$ Istituto di Metodologie per l'Analisi Ambientale-CNR, Potenza, Italy.

${ }^{4}$ Laboratory of Atmospheric Physics, Aristotle University of Thessaloniki, Thessaloniki, Greece.

${ }^{5}$ Max-Planck-Institut für Meteorologie, Hamburg, Germany.

${ }^{6}$ Institute of Physics, National Academy of Sciences of Belarus, Minsk, Belarus.

${ }^{7}$ Physics Department, University of Lecce, Lecce, Italy.

${ }^{8}$ Institute of Electronics, Bulgarian Academy of Sciences, Sofia, Bulgaria.

${ }^{9}$ Leibniz Institute for Tropospheric Research, Leipzig, Germany.

${ }^{10}$ Centre Suisse d'Electronique et de Microtechnique SA, Neuchâtel, Switzerland.

Copyright 2008 by the American Geophysical Union. 0148-0227/08/2007JD009028
}

the atmosphere [Zender, 2004]. According to Kinne et al. [2006], mineral dust accounts for about $75 \%$ of the global aerosol mass load and $25 \%$ of the global aerosol optical depth. The African continent, especially its northern part

\footnotetext{
${ }^{11}$ Euro-Mediterranean Centre on Insular Coastal Dynamics, University of Malta, Valletta, Malta.

${ }^{12}$ Now at World Meteorological Organization, Geneva, Switzerland.

${ }^{13}$ Earth Sciences Division, Barcelona Supercomputing Centre, Barcelona, Spain.

${ }^{14}$ Institute of Geophysics, Polish Academy of Sciences, Warsaw, Poland.

${ }^{15}$ CNISM and Dipart. di Scienze Fisiche, Università di Napoli Federico II, Napoli, Italy.

${ }^{16}$ Service d'Aéronomie-IPSL, Université Pierre et Marie Curie (UP6), Paris, France.

${ }^{17}$ CETEMPS and Dipartimento di Fisica, Università Degli Studi L'Aquila, L'Aquila, Italy.

${ }^{18}$ Remote Sensing Laboratory, Universitat Politecnica di Catalunya, Barcelona, Spain.

${ }^{19}$ Forschungszentrum Karlsruhe, IMK-IFU, Garmisch-Partenkirchen, Germany.

${ }^{20}$ Meteorologisches Institut der Universität München, Munich, Germany.

${ }^{21}$ Leibniz-Institut für Atmosphärenphysik, Universität Rostock, Kühlungsborn, Germany.
} 
(Sahara desert), the Saudi Arabian regions, as well as the Asian continent (eastern areas), are the main sources of dust around the globe [Dayan et al., 1991; Duce, 1995; Chiapello et al., 1997; Marticorena et al., 1997; Prospero et al., 2002; Engelstaedter and Washington, 2007].

[3] The latest report of the Intergovernmental Panel on Climate Change (IPCC) [Forster et al., 2007] only considers the dust-related anthropogenic effect which is about $20 \%$ of the total dust radiative effect. Therefore the role of the natural dust particles becomes very important in radiative forcing issues. According to that report the climatic role of dust aerosol is now better quantified than in the previous IPCC report [Intergovernmental Panel on Climate Change, 2001]. Thus, a total direct aerosol radiative forcing combined across all aerosol types can now be given as $-0.5 \pm$ $0.4 \mathrm{~W} / \mathrm{m}^{2}$, with a medium-low level of scientific understanding. However, between the two IPCC reports the overall uncertainties in the radiative forcing effect of dust (anthropogenic and natural) remain the same and still very high. These uncertainties can only be reduced by better quantifying the vertical and horizontal distribution of dust in the globe. Lidar network measurements of the vertical distribution of the optical properties of dust can contribute to such quantification.

[4] Mineral dust particles play an important role in the Earth's radiation balance and climate, by acting as cloud condensation nuclei (CCN) and thereby determine the concentration of the initial droplets, albedo, precipitation formation and lifetime of clouds [Levin et al., 1996; Miller et al., 2004; Levin et al., 2005]. Sokolik et al. [2001] mentioned that the existing uncertainties are caused in part by the limited data on dust climatology and our incomplete understanding of the processes responsible for the production, transport, physical and chemical evolution, and removal of mineral aerosols at various space scales and timescales. Out of these issues, the transport process can be addressed by European Aerosol Research Lidar Network (EARLINET) [Bösenberg et al., 2003], which focuses on the observation of transport of Saharan dust across Europe.

[5] It is well known that a large amount of Saharan dust is transported over the Mediterranean Sea mainly because of cyclone activity inside and around the area [Prospero, 1996; Dunion and Velden, 2004; Balis et al., 2006]. Before the EARLINET network was established, the Saharan dust transport over Europe was systematically studied mainly over the Mediterranean region by satellite observations [Dulac et al., 1992; Prospero, 1996; Moulin et al., 1997a; Moulin et al., 1997b] and ground-based Sun photometers [Holben et al., 2001]. Very few publications existed on the vertical distribution of desert dust particles over the European continent and the Mediterranean Sea [e.g., Hamonou et al., 1999; Gobbi et al., 2000; di Sarra et al., 2001; Carnuth et al., 2002; Gobbi et al., 2002; Dulac and Chazette, 2003; Gobbi et al., 2004].

[6] The coexistence of lofted Saharan dust plumes over areas with significant anthropogenic aerosol sources in the boundary layer [Pérez et al., 2006a] does not allow their accurate separation, when examining satellite or groundbased columnar measurements. Lidar measurements are in that sense essential since they provide very valuable information on the vertical distribution of the optical properties of aerosols of desert origin. A multistep approach for the discrimination between the different aerosol types and more specifically, for the dust aerosols has been adopted: (1) identification of the dust layers, (2) in addition to step 1, air mass back-trajectories are calculated to identify the aerosol source region, (3) in addition to steps 1 and 2, and depending on the lidar station, the aerosol layers are characterized by the use of the Ångström exponent, the depolarization and lidar ratio profiles.

[7] Since May 2000, the EARLINET network has provided systematic lidar observations of vertical profiles of Saharan dust aerosols over the European continent on a coherent network basis. These observations have allowed the establishment of a significant database of vertical profiles of Saharan dust optical properties. Within EARLINET, typical dust outbreaks have been analyzed in detail over the southeastern Mediterranean [De Tomasi et al., 2003; Papayannis et al., 2005] and the northern Europe [Ansmann et al., 2003; Müller et al., 2003]. Two studies were also reported on the optical properties of Saharan dust detected during 2 years in the eastern Mediterranean area [Balis et al., 2004; Balis et al., 2006] and during 3 years in the central Mediterranean region [Mona et al., 2006].

[8] In this paper we present an analysis of the Saharan dust observations and the characteristics and optical properties of the desert aerosols detected over the European continent in the period from May 2000 to December 2002 in the frame of the EARLINET network. The paper is organized as follows. Section 2 gives a brief presentation of the objectives of the EARLINET network and describes the instrumentation and methods available. A description of the air mass back-trajectory model and the Dust Regional Atmospheric Model (DREAM) is also given. The first part of section 3 gives an overview of the spatial and seasonal distribution of the dust aerosol particles over the European continent during Saharan dust outbreaks using the DREAM model calculations. We also present the basic results from a cluster analysis performed for the trajectories that correspond to all days classified as "model-forecasted" dust days by the DREAM model to classify the air mass trajectories into distinct dust transport patterns from Africa to Europe. Finally, the analysis of the systematic lidar measurements performed by the EARLINET network during the Saharan dust outbreaks, in the period 1 May 2000 up to 31 December 2002, as well as the aerosol dust layers characteristics and optical properties, are presented. Section 4 presents our concluding remarks.

\section{Instrumentation and Methods \\ 2.1. EARLINET Network}

[9] During the specific period considered, EARLINET was composed of 20 stations distributed over Europe (Figure 1), using advanced laser remote sensing instruments, to measure directly the vertical distribution of aerosols in the planetary boundary layer (PBL) and the adjacent free troposphere (FT). It was supported by a suite of conventional instrumentation (Sun photometers, ultravioletB (UV-B) radiometers, spectral photometers, meteorological stations, etc.) as described by Bösenberg et al. [2003]. The stations' acronyms, the coordinates, the geographical sectors, the laser wavelengths used, and the aerosol retrieval method are given in Table 1. 


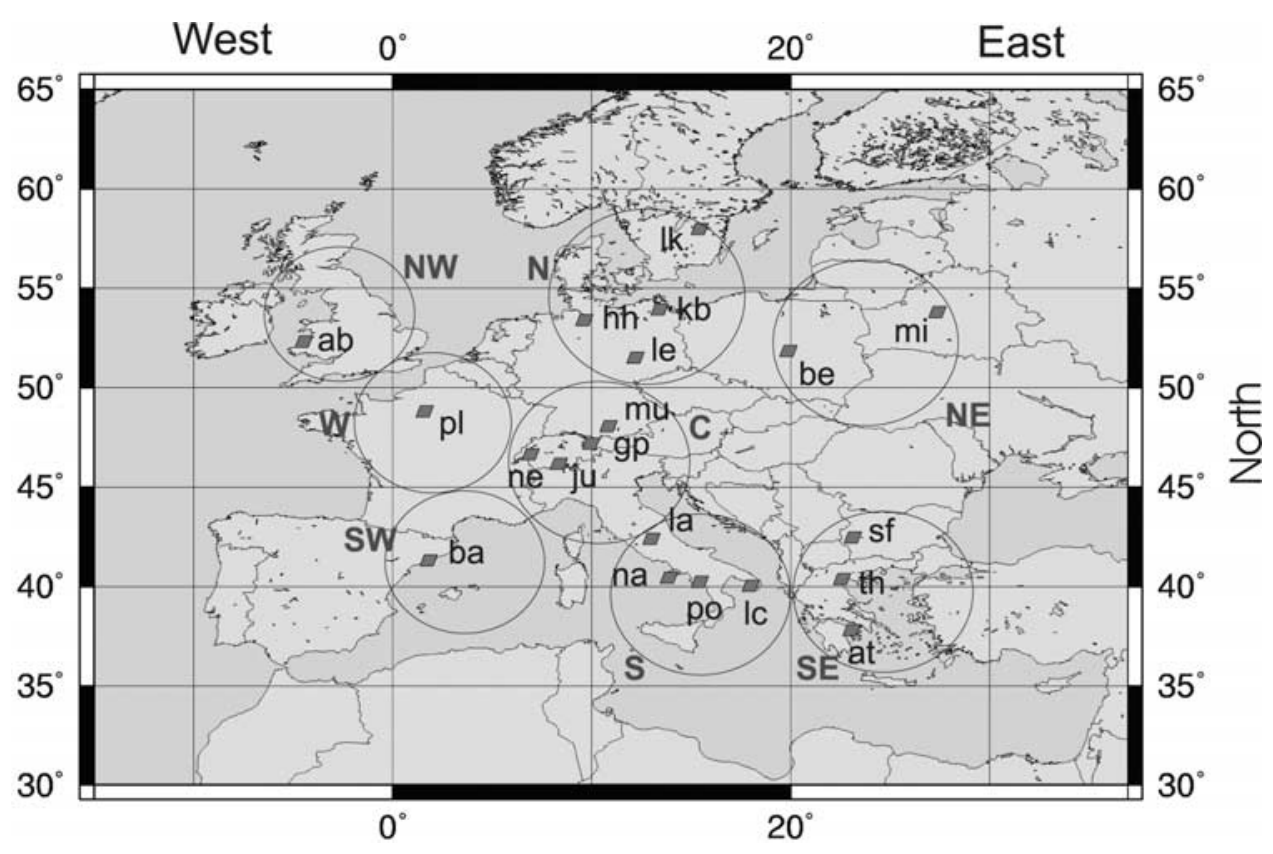

Figure 1. European Aerosol Research Lidar Network (EARLINET) lidar stations in the European continent. Special points indicate the location of the station. Circles denote the corresponding geographical sector. The acronym of each station is also given.

[10] The overall objectives of EARLINET are (1) to establish a comprehensive and quantitative climatological database for the horizontal and vertical distribution and variability of aerosol over Europe, (2) to provide aerosol data with unbiased sampling, and (3) to provide the necessary database for validating and improving numerical models describing the evolution of aerosol properties and their influence on climate and environmental conditions. In particular, during the considered period, 11 EARLINET stations were equipped with Raman channels (see Table 1) and therefore provided direct and independent measurements of the vertical profiles of aerosol extinction and backscatter coefficients [Ansmann et al., 1992]. This allowed the collection of the most extended database of dust vertical profiles obtained without critical assumption on the extinction to backscatter ratio, which is necessary for the elastic backscatter lidar retrievals. The spatial distribution of the EARLINET stations provides a good geographical coverage for the investigation of the long-range transport phenomena of Saharan dust aerosols across the European continent.

\subsection{Lidar Measurements Methodology}

[11] Across Europe, 20 stations (Figure 1 and Table 1) were deployed using elastic backscatter and Raman lidar systems to measure the vertical profiles of the aerosol backscatter and extinction coefficients at various wavelengths between 351 or $355 \mathrm{~nm}$ up to $1064 \mathrm{~nm}$ [Bösenberg et al., 2003]. In the frame of EARLINET the lidar systems were quality assured by performing direct intercomparisons, both at hardware and software levels [Böckmann et al., 2004; Matthias et al., 2004a; Pappalardo et al., 2004]. The lidar measurements were performed regularly: three times, distributed over $2 \mathrm{~d}$ per week [Bösenberg et al., 2003]. In addition, when Saharan dust presence over at least one EARLINET site was forecasted by DREAM, the measuring schedule was altered and the concerned stations performed additional lidar measurements after an alert was issued by the NTUA group, who coordinated the monitoring of the dust outbreaks within the network. The alerts were issued 24 to $36 \mathrm{~h}$ prior to the arrival of dust aerosols over the EARLINET sites. Ancillary observations to locate the Saharan dust plume over a measuring site included satellite aerosol-related data (aerosol index from Total Ozone Mapping Spectrometer (TOMS), aerosol load from Moderate Resolution Imaging Spectroradiometer (MODIS), and realcolor pictures from the Sea-Viewing Wide Field-of-View Sensor (SeaWiFS) sensors) for mutual comparison with the aerosol data from dust forecast models.

[12] The aerosol vertical profiles captured by the EARLINET stations during the Saharan dust outbreaks were all stored in a central database, following archiving rules of the network [Bösenberg et al., 2003]. Cloud screening was performed prior to the storage of the data in the central database.

[13] A set of criteria was then applied to characterize the stored aerosol lidar data as "Saharan dust" profiles. The first criterion was that the aerosol profile should contain at least one distinct aerosol layer above the PBL retrieved following the EARLINET criterion [Matthias et al., 2004b]. The second criterion was that the specific aerosol layer should originate from the Saharan region. The origin of this layer was identified on the base of the three-dimensional 4-d air mass back trajectory analysis. In some very limited cases, a longer air mass back-trajectory analysis (up to 57 d) was needed due to more complex meteorological conditions or long, indirect advection (e.g., via the Atlantic Ocean) involved in the dust transport processes. In order to verify that the vertical level at which the trajectory passed over the desert area contained mineral dust, we used the DREAM model forecasts as a third criterion, which took 
Table 1. EARLINET Lidar Stations, Their Geographical Coordinates and Location, the Wavelengths, and Retrieval Methods Used

\begin{tabular}{|c|c|c|c|c|c|c|}
\hline Lidar Station & Station Code & Latitude $\left({ }^{\circ}\right)$, Longitude $\left({ }^{\circ}\right)$ & Sector & Station Altitude $(\mathrm{m})$ & Backscatter Wavelength (nm) & Retrieval Method \\
\hline Aberystwyth - UK & $\mathrm{ab}$ & $52.40 \mathrm{~N}, 4.06 \mathrm{~W}$ & NW & 15 & 355,532 & Raman/Klett \\
\hline Athens - GR & at & $37.97 \mathrm{~N}, 23.79 \mathrm{E}$ & SE & 200 & 355,532 & Raman/Klett \\
\hline Barcelona - E & ba & $41.39 \mathrm{~N}, 2.12 \mathrm{E}$ & SW & 115 & 532,1064 & Klett \\
\hline Belsk - PO & be & $51.50 \mathrm{~N}, 20.50 \mathrm{E}$ & NE & 188 & 532,694 & Klett \\
\hline Garmisch -Partenkirchen - D & gp & $47.64 \mathrm{~N}, 11.06 \mathrm{E}$ & $\mathrm{C}$ & 730 & 355,532 & Extended Klett \\
\hline Hamburg - D & hh & $53.57 \mathrm{~N}, 9.97 \mathrm{E}$ & $\mathrm{N}$ & 25 & $355,532,1064$ & Raman/Klett \\
\hline Jungfraujoch - $\mathrm{CH}$ & ju & $46.55 \mathrm{~N}, 7.98 \mathrm{E}$ & $\mathrm{C}$ & 3580 & $355,532,1064$ & Raman/Klett \\
\hline Kühlungsborn - D & $\mathrm{kb}$ & $54.12 \mathrm{~N}, 11.77 \mathrm{E}$ & $\mathrm{N}$ & 70 & 532,1064 & Raman/Klett \\
\hline L'Aquila - I & la & $42.34 \mathrm{~N}, 13.33 \mathrm{E}$ & $\mathrm{S}$ & 683 & 351 & Raman/Klett \\
\hline Lecce - I & lc & $40.33 \mathrm{~N}, 18.10 \mathrm{E}$ & $\mathrm{S}$ & 30 & 351 & Raman/Klett \\
\hline Leipzig - D & le & $51.35 \mathrm{~N}, 12.43 \mathrm{E}$ & $\mathrm{C}$ & 90 & $355,532,1064$ & Raman/Klett \\
\hline Linköping - S & $\mathrm{lk}$ & $58.39 \mathrm{~N}, 15.58 \mathrm{E}$ & $\mathrm{N}$ & 70 & 355,532 & Klett \\
\hline Minsk - BE & $\mathrm{mi}$ & $53.92 \mathrm{~N}, 27.38 \mathrm{E}$ & $\mathrm{E}$ & 200 & 532,694 & Klett \\
\hline Munich - D & $\mathrm{mu}$ & $48.15 \mathrm{~N}, 11.57 \mathrm{E}$ & $\mathrm{C}$ & 549 & 355,532 & Klett/Multiangle \\
\hline Napoli - I & na & $40.83 \mathrm{~N}, 14.18 \mathrm{E}$ & $\mathrm{S}$ & 118 & 351 & Raman/Klett \\
\hline Neuchâtel - CH & ne & $47.00 \mathrm{~N}, 6.95 \mathrm{E}$ & $\mathrm{C}$ & 450 & 355,532 & Klett \\
\hline Palaiseau - F & $\mathrm{pl}$ & $48.42 \mathrm{~N}, 2.16 \mathrm{E}$ & W & 156 & 532 & Klett \\
\hline Potenza - I & po & $40.60 \mathrm{~N}, 15.72 \mathrm{E}$ & $\mathrm{S}$ & 760 & 355,532 & Raman/Klett \\
\hline Sofia - BG & sf & $42.70 \mathrm{~N}, 23.30 \mathrm{E}$ & SE & 550 & 532,1064 & Klett \\
\hline Thessaloniki - GR & th & $40.51 \mathrm{~N}, 22.93 \mathrm{E}$ & SE & 40 & 355,532 & Raman/Klett \\
\hline
\end{tabular}

into account convective activities over the Saharan area. Therefore, the Saharan dust cases considered here (referred to as "model-forecasted" dust days) were only those fulfilling all three above-mentioned criteria.

\subsection{Air Mass Trajectories}

[14] The German Weather Service (DWD) provided 4-d backward trajectories at each EARLINET lidar station for two arrival times per day and for six arrival pressure levels between 200 and $975 \mathrm{hPa}$ [Bösenberg et al., 2003]. Additionally, 4-d (and some times longer) air mass back trajectories were computed using the National Oceanic and Atmospheric Administration (NOAA) Hybrid Single-Particle Lagrangian Integrated Trajectory (HYSPLIT-4) model [Draxler and Hess, 1998] from the NOAA Air Resources Laboratory, Silver Spring, Maryland, USA. The HYSPLIT trajectories were computed at several altitudes (mainly between 2000 and $6000 \mathrm{~m}$ ) every $6 \mathrm{~h}$ for the period May 2000 to December 2002. Trajectory information was also derived from the 10-d NOAA Climate Monitoring and Diagnostics Laboratory (CMDL) model (http:// www.cmdl.noaa.gov/traj/plots/zug.html) and, in selected cases, from the FLEXTRA model (http://zardoz.nilu.no/ $\sim$ andreas/flextra+flexpart.html). Usually the deviation between the calculated and the actual track of an air parcel is of the order of $10-20 \%$ of the travel distance. This is because the accuracy depends on the interpolation of meteorological data, on assumptions of vertical transport, on wind field errors, on truncation errors and on the synoptic condition, where higher wind speeds give better accuracies of the trajectories [Stohl, 1998]. Nevertheless, trajectories provide a useful tool to characterize patterns in the large-scale motion.

\subsection{DREAM Dust Model}

[15] The dust forecast is based on the operational outputs (aerosol dust load) of the DREAM (operated then at Malta at the Centre on Insular Coastal Dynamics - ICOD and now in Barcelona, Spain: http://www.bsc.es/projects/earthscience/ DREAM/) and the Skiron models (operated in Athens, Greece: http://forecast.uoa.gr) [Nickovic et al., 2001] freely available on the Web. DREAM simulates or predicts the three-dimensional field of the dust concentration in the troposphere [Nickovic et al., 2001], taking into account all major processes of the dust life cycle, such as dust production, horizontal and vertical diffusion, and advection and wet and dry deposition. The model also includes the effects of the particle size distribution on aerosol dispersion. In DREAM the dust mass is described by particles with four sizes, resulting from the structure of desert soils based on the content of clay, small silt, large silt, and sand. The model numerically solves the Euler-type mass partial differential equation by integrating it spatially and temporally. The dust production is parameterized using the near-surface wind and thermal conditions, as well as soil features. The dust production mechanism is based on the viscous/turbulent mixing, shear-free convection-diffusion, and soil moisture. The alert for additional measurements was distributed by the NTUA group to the network, when DREAM forecasted a dust loading greater than $0.1 \mathrm{~g} / \mathrm{m}^{2}$ over at least one EARLINET site. In the following, we will indicate these days as "model-forecasted" dust days.

\section{Results and Discussion}

[16] In order to give an overview of the spatial and seasonal distribution of the dust aerosol particles over the European continent, a seasonal analysis derived from the DREAM calculations is presented. Then the analysis of the systematic lidar measurements performed by the EARLINET network during the Saharan dust outbreaks as well as the aerosol dust layers' characteristics and optical properties, will be presented. During the reporting period (1 May 2000 to 31 December 2002) more than 70 events $(130-150 \mathrm{~d})$ (each dust event lasted from 1 up to $3-4 \mathrm{~d}$ ) of free tropospheric Saharan dust transport (fulfilling the three criteria presented in section 2) from Africa to Europe were observed over the EARLINET sites. No lidar measurements were taken, under relevant dust transport events, when unfavorable meteorological conditions prevailed (low-lying clouds or rainy conditions) over each specific measuring site (conditions occurred in about $50-65 \%$ of the cases, depending on the geographic location) (see section 3.2). 


\subsection{DREAM Model Calculations and Trajectory Analysis}

[17] As outlined by Querol et al. [2002], the seasonal patterns in the transport of Saharan dust toward Europe are related to: (1) the variation of the emission areas throughout the year, (2) the occurrence of dust injection processes, and (3) the meteorological patterns which favor the transport toward the region of study. These aspects are mainly modulated by the latitudinal shift of the general circulation of the atmosphere.

[18] As depicted in Figure 2a, the modeled seasonal mean dust load captures the well-known features of dust distribution in the source regions [Tegen et al., 2002]. The zone of maximum dust transport is located over the Atlantic coast at $20^{\circ} \mathrm{N}$ in summer. The winter maximum shifts to $5^{\circ} \mathrm{N}$ (Sahel region), which is not included in the domain of simulation. The seasonal patterns toward Europe show a maximum dust load in the central and eastern Mediterranean during spring, and in the central and western Mediterranean during summer, which is in good agreement with the observations discussed by Moulin et al. [1998]. During autumn, although the dust load over North Africa is relatively low, the dust distribution in the Mediterranean remains qualitatively and quantitatively similar to the summer season.

[19] Concerning the vertical extent of the dust plume (in $\mathrm{g} / \mathrm{m}^{2}$ ) shown in Figure $2 \mathrm{~b}$ (presented for east-west (EW) and south-north (SN) cross sections at $33^{\circ} \mathrm{N}$ and $10^{\circ} \mathrm{E}$, which give a typical value of dust plume in the central Mediterranean region), the model shows comparably high mean concentration profiles in spring and summer, mostly for the eastern Mediterranean stations. Finally, much less dust activity is observed in the winter period. According to Figure $2 b$, dust particles penetrate the geographical area located between 20 and $40^{\circ} \mathrm{E}$ (longitude) and $40-47^{\circ} \mathrm{N}$ (latitude) reaching a relatively great height of $7000 \mathrm{~m}$ during springtime.

[20] Additional back-trajectory analysis (not shown) was also performed using the HYSPLIT-4 model to support the DREAM results. A cluster analysis was performed for the trajectories that correspond to all days characterized as "model-forecasted" dust days by the DREAM model according to the method proposed by Dorling et al. [1992], to classify the air mass trajectories into distinct dust transport patterns from Africa to Europe. Analyzing the main pathways of Saharan dust transport over Europe in the height region between 3 and $5 \mathrm{~km}$, we see that western Europe seems to be mostly affected by the western Saharan (WS) region. The central and northern European regions are mostly affected by WS and central Saharan (CS) regions. Finally, the southern and southeastern European regions seem to be mostly affected by the CS and the eastern Saharan (ES) regions. These findings are in agreement with similar findings from specific studies concerning central Europe and Italy [Barkan et al., 2005], Potenza (Italy) [Mona et al., 2006], and Athens (Greece) [Papayannis et al., 2005].

\subsection{EARLINET Observations of Saharan Dust Over Europe}

[21] The occurrence of dust transport over each EARLINET station during the reported period (May 2000 to December 2002) is given in Figure 3, as a function of the number of dust days. Dust transport events are more frequent as the distance of the measuring site from the various Saharan dust areas gets shorter. However, the stations near or just north of the Alps also report rather frequent observations of dust plumes, mostly associated with prefrontal situations [Zängl and Hornsteiner, 2007]. Figure 3 also reports the total number of "model-forecasted" days (white column) of Saharan dust transport over the measuring sites and the respective percentage (\%) of observed to forecasted number of days which is indicated at the top of each column. It is evident that the number of forecasted events is always higher than the observed ones. This is due to the combination of two main factors: alerts for Saharan dust measurements were distributed to the stations in cases of forecast dust events; sometimes lidar measurements over a specific measuring site were not performed due to unfavorable meteorological conditions (low-lying clouds or rainy conditions) or technical problems (i.e., laser breakdown) which inhibited the operation of the lidar system. In spite of this, most stations collected measurements for more than $20-30 \%$ of the "model-forecasted" dust days. However, it is important to underline that about 600 observations of Saharan dust distributed over the entire European continent have been collected: this is the most extended database concerning the vertical profiles of the desert dust optical properties.

[22] In Figures 4a to $4 \mathrm{~d}$ we present the number of dust days per month (for the discussed period) of successful lidar observations (gray columns) (fulfilling all three dust criteria, cf. section 2.2), compared with the "model-forecasted" (white columns) dust days (mass load $>0.1 \mathrm{~g} / \mathrm{m}^{2}$, cf. section 2.4) for four different European sites, representative of their geographic location and having more than $40 \mathrm{~d}$ of total dust observations: Barcelona (Spain), Potenza (Italy), Neuchâtel (Switzerland), and Athens (Greece). No significant year-to-year variation (from May 2000 to December 2002) was found for any station concerning the number of dust days observed per station, except for the Athens station, where this number is increased mainly in 2002 due to favorable meteorological conditions leading to more dust transport over that area. However, a clear annual cycle is visible with a minimum in winter.

[23] The corresponding mean number of observed (gray column) and "model-forecasted" dust days per month for the reported period for the four selected sites is plotted in Figures $5 \mathrm{a}$ to $5 \mathrm{~d}$. Error bars represent the standard deviation from the mean of the "model-forecasted" days per month. The respective percentage (\%) of observed to forecasted number of days is also indicated at the top of each column. It is clear from these figures and based on the mean number of "model-forecasted" dust days that the spring months (e.g., May) are the most favorable for dust aerosol transport over Europe. In addition, we can observe that during summer and autumn months, the mean number of dust days forecasted remains important. The lidar observations roughly follow the annual cycle predicted by the dust model. Both Figures 4 and 5 show that the number of events captured at the four selected sites is in reasonable agreement with the DREAM forecast in terms of temporal and seasonal behavior.

[24] To get a more representative view of the seasonal variation of the observed Saharan dust days over the 

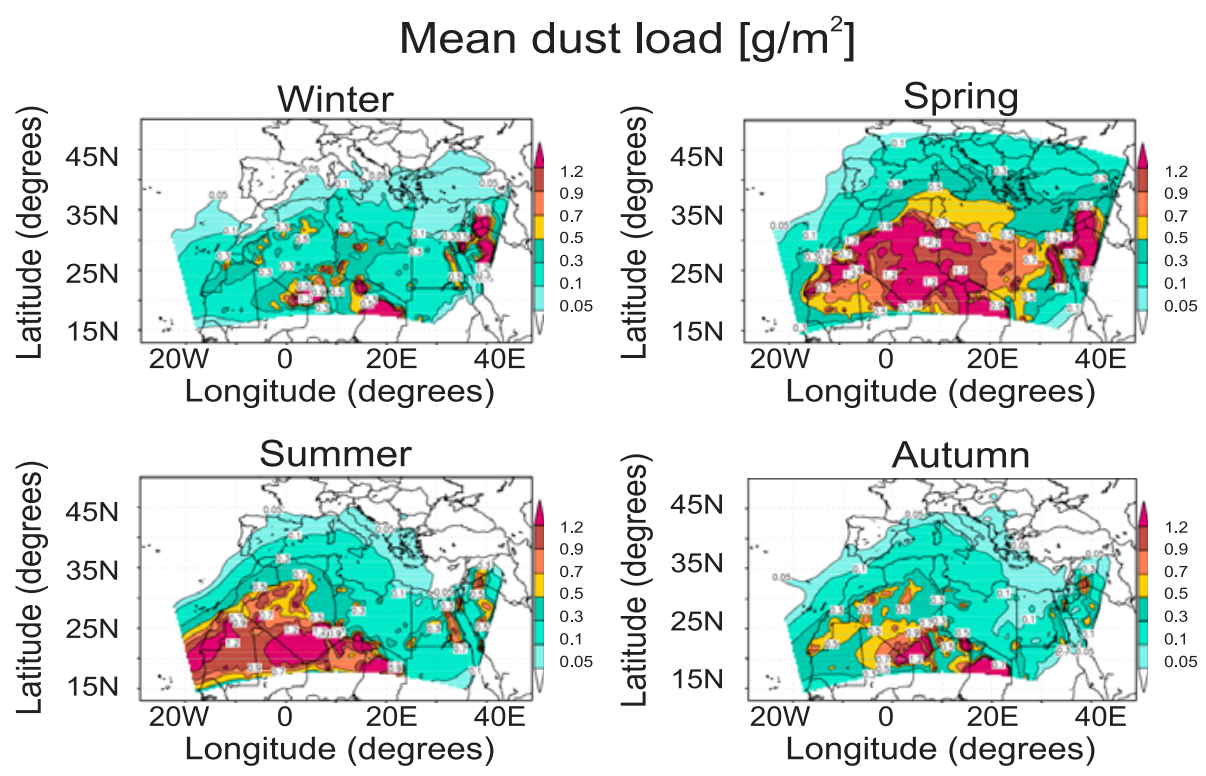

(a)
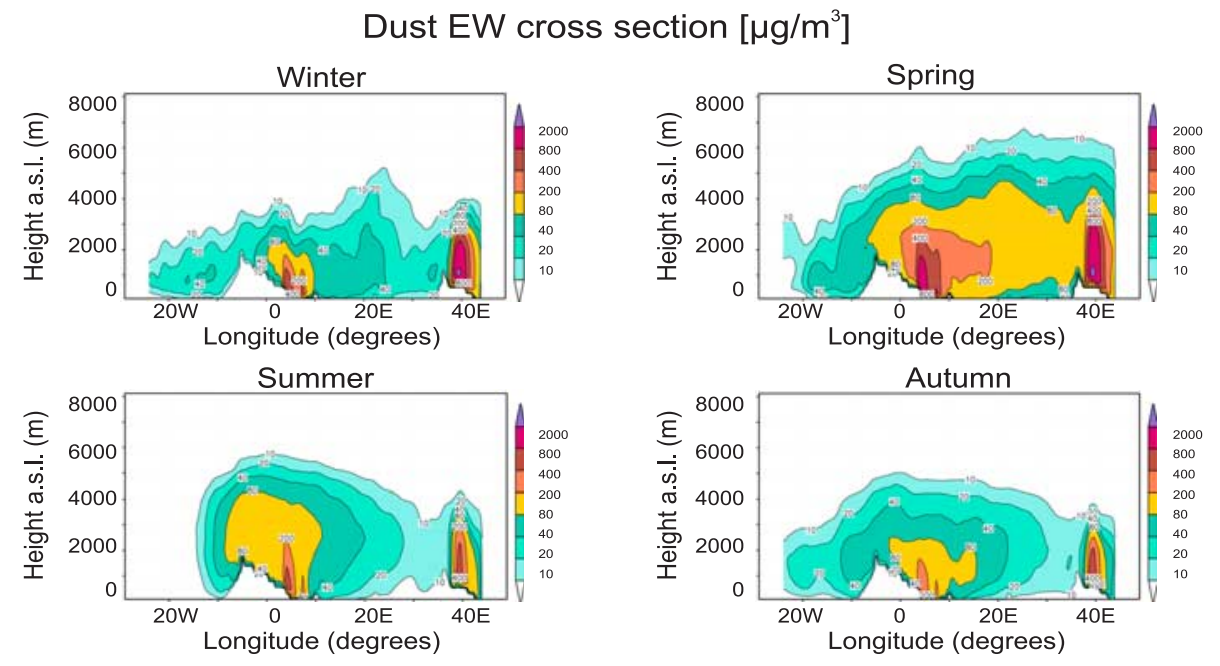

Dust SN cross section $\left[\mu \mathrm{g} / \mathrm{m}^{3}\right]$
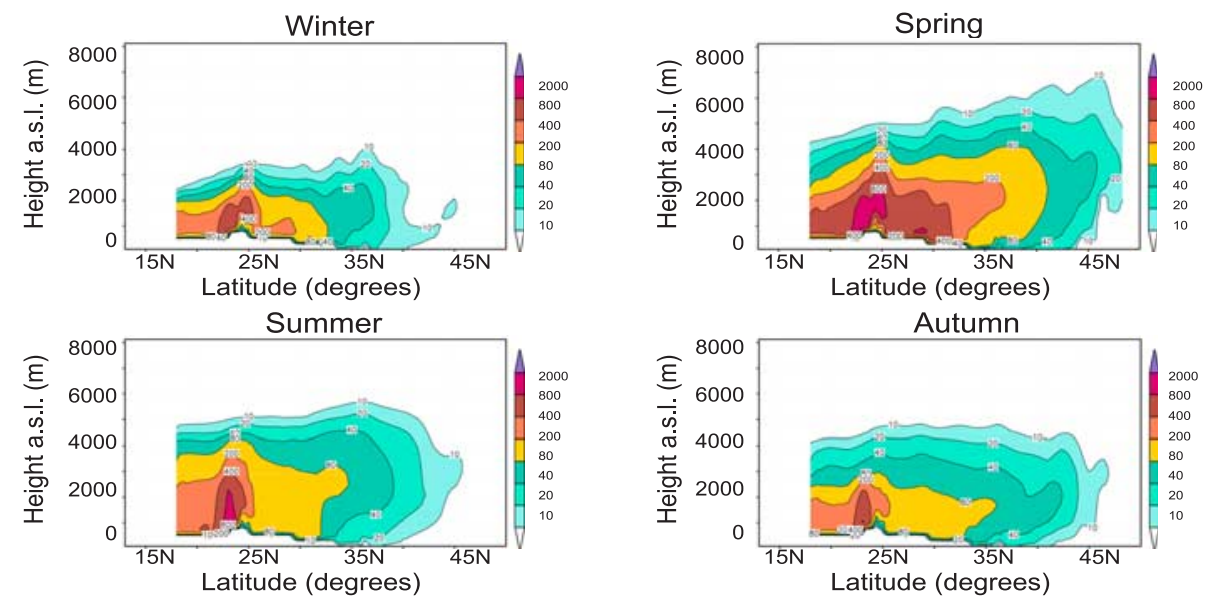

(b)

Figure 2. (a) Mean dust load $\left(\mathrm{g} / \mathrm{m}^{2}\right)$ per season as calculated by the DREAM model for the studied period (May 2000 to December 2002). (b) East-west (EW) height cross section (over $33^{\circ} \mathrm{N}$ ) and southnorth (SN) (over $\left.10^{\circ} \mathrm{E}\right)$ of the dust concentration $\left(\mu \mathrm{g} / \mathrm{m}^{3}\right)$ per season, computed by the DREAM model for the studied period (May 2000 to December 2002). 


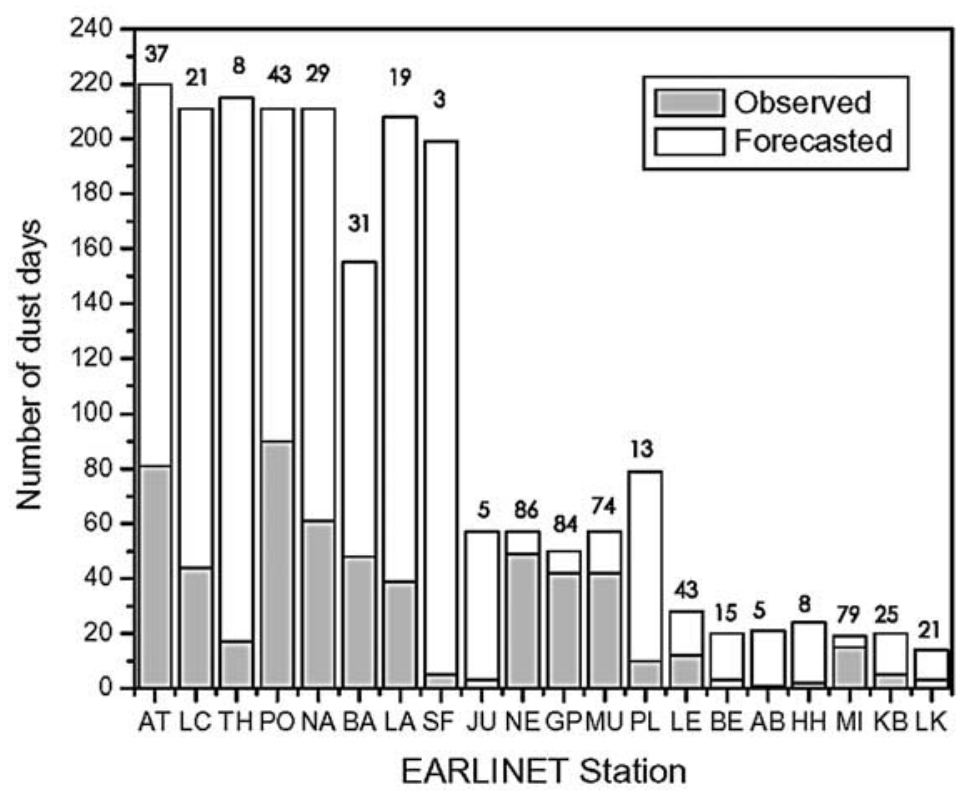

Figure 3. Saharan dust outbreaks (in number of days) observed (gray column) and "model-forecasted" (white column) per EARLINET station (May 2000 to December 2002). The respective percentage (\%) of observed to forecasted number of days is also indicated at the top of each column.

European continent we grouped the EARLINET sites into geographical sectors: northern $(\mathrm{N})$, northeastern $(\mathrm{NE})$, central $(\mathrm{C})$, western $(\mathrm{W})$, southwestern $(\mathrm{SW})$, south $(\mathrm{S})$, and southeastern (SE) sites (cf. Figure 1). Figure 6 shows the seasonal variation of the mean number of measurement days for the period studied (May 2000 to December 2002), per geographical sector (cf. Table 1 and Figure 1). Figure 6 shows that most dust episodes were observed during the spring, summer, and early autumn months, while the fewest were observed during the winter period. The dust days finally observed by EARLINET stations in the different geographical sections have a seasonal coverage that follows the expected one: the mean number of dust episodes observed, per season, is much higher in the $\mathrm{S}$ and $\mathrm{SE}$ European regions due to the prevailing meteorological conditions (direction of wind flow) in conjunction with their vicinity to the Sahara desert.

[25] The findings for $\mathrm{S}$ and SE Europe are in good agreement with those reported earlier by Moulin et al. [1998], based on an 11-year (1983-1994) satellite climatology, only for the spring and summer period, since they claimed that during autumn and winter months there is very little dust transport. Both EARLINET observations (Figures 4a to $4 \mathrm{~d}, 5 \mathrm{a}$ to $5 \mathrm{~d}$, Figure 6 , and Figures $7 \mathrm{a}$ to $7 \mathrm{~d}$ ) and DREAM climatology (Figures 2a and 2b) outline that the autumn period is also an important dust transport season. This is in good agreement with the findings of Barnaba and Gobbi [2004] and of Antoine and Nobileau [2006]. The C and SW sectors still exhibit quite a significant number of dust days, while the remaining sectors $(\mathrm{N}, \mathrm{NE}, \mathrm{W})$ show low dust transport activity. The agreement of the model forecast with results from previous studies demonstrates that, as a whole, EARLINET Saharan dust measurements collected in May 2000 to December 2002 provide a representative database for the description of the Saharan dust intrusion over Europe.

\subsection{Dust Aerosol Characteristics}

[26] In this section, dust layer characteristics and dust aerosol optical properties observed by lidar over the European continent are presented. First of all, the altitude ranges where dust was detected are discussed, thanks to the lidar capability to investigate the aerosol vertical layering. Then, desert dust optical properties are discussed in terms of monthly mean values and all the period mean profiles. Finally, the 32-month mean values of the aerosol optical depth and lidar ratio values calculated within the detected dust layers are discussed.

\subsubsection{Dust Layer Characteristics}

[27] Let us first examine the variation of the dust layer characteristics over the European continent. The presence of dust in the atmosphere (in form of layer(s) at various altitudes) can be observed by lidar, either at the aerosol extinction [Mattis et al., 2002; De Tomasi et al., 2003; Balis et al., 2004; Mona et al., 2006] or the backscatter vertical profile [Hamonou et al., 1999; Gobbi et al., 2000; Gobbi et al., 2004]. In some cases the aerosol vertical structure may be very complex, as various dust layers may be present simultaneously at different altitudes.

[28] We calculated four dust layer parameters: the base, the top, the thickness, and the center of mass of the dust layer, following the procedure recently proposed by Mona et al. [2006]. Thus, the base of the dust aerosol layer corresponds to the lowest point of a strong increase in the aerosol backscatter profile over the retrieved PBL height [Matthias et al., 2004b]. In addition, under certain circumstances (less than about $5 \%$ of the cases according to the DREAM model) Saharan dust can markedly affect the lowermost levels of the atmosphere, and then the base of the dust aerosol layer is found near the ground level. In our data analysis we have considered both possibilities.

[29] On the other hand, the top of the desert dust layer is located at an altitude at which both the aerosol backscatter 

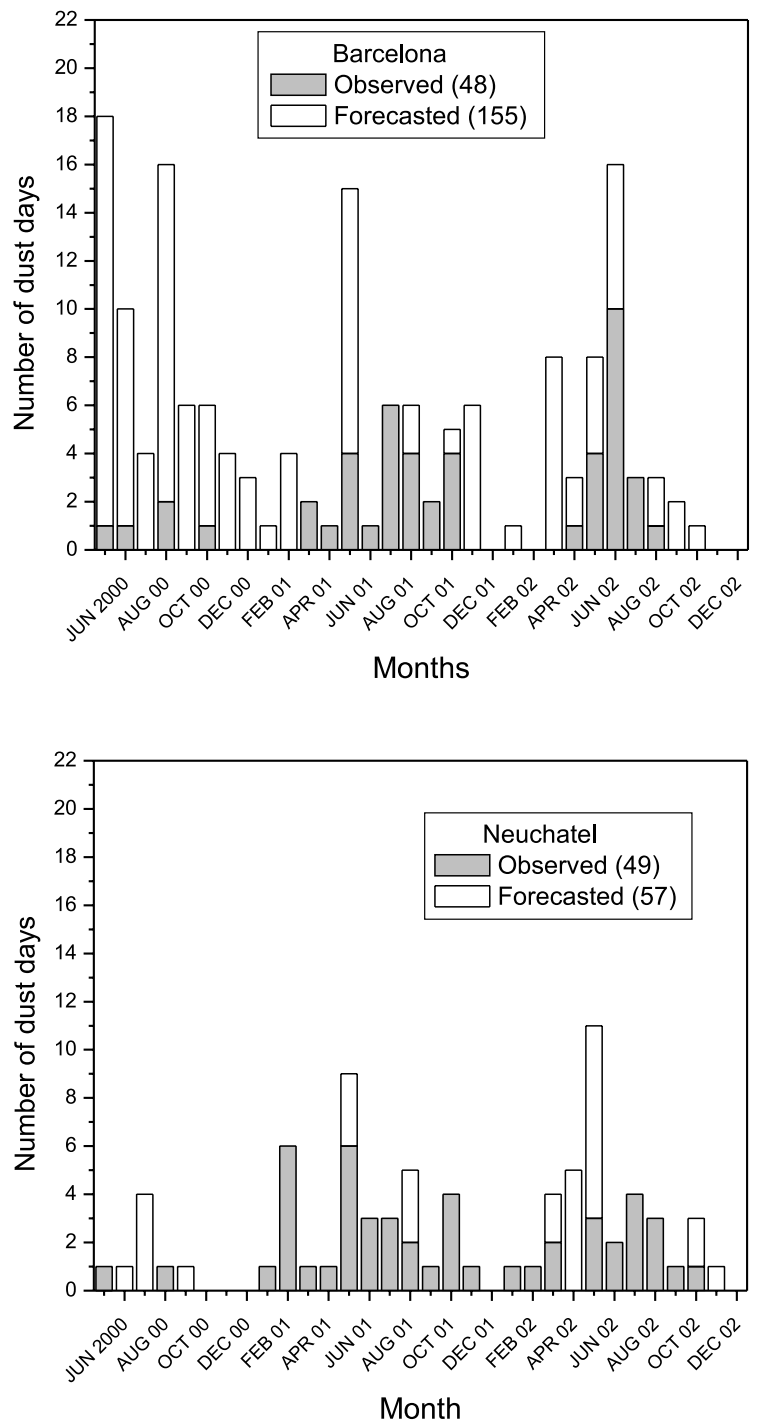
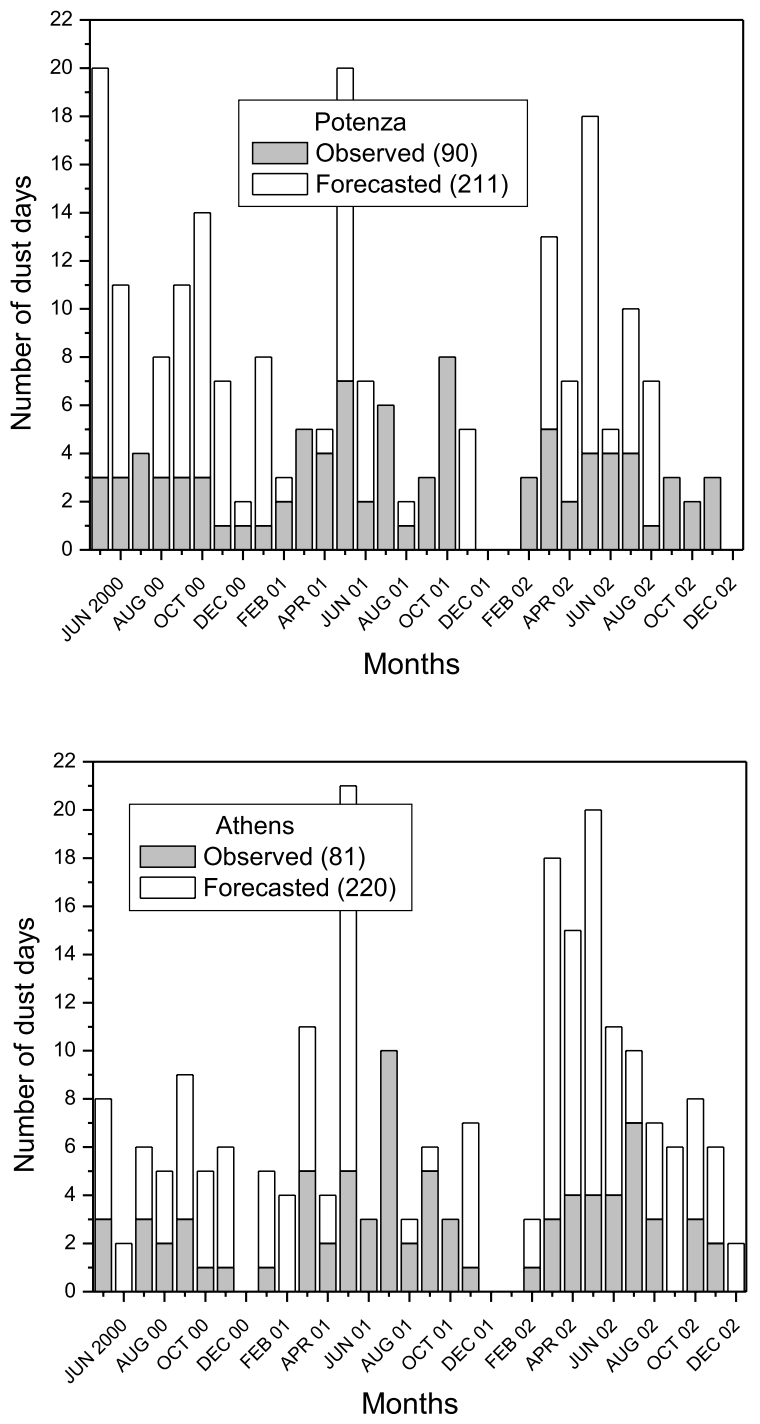

Figure 4. Number of dust days observed (gray column) per month/year for four representative EARLINET stations together with the number of "model-forecasted" dust days (white column) for (a) Barcelona (Spain), (b) Potenza (Italy), (c) Neuchâtel (Switzerland), and (d) Athens (Greece) (May 2000 to December 2002). The corresponding total number of days (observed or forecasted) is given in parenthesis inside the legend.

and its first derivative become zero within the experimental error. Knowing the base and the top of the dust layer, its thickness can be calculated. The center of mass is estimated by the calculation of the backscatter weighted altitude [Mona et al., 2006]. This quantity gives information about the altitude where the most relevant part of the aerosol load is located, and it coincides with the true center of mass, if both composition and size distribution of the particles are constant with altitude.

[30] Table 2 reports the mean (with the corresponding standard deviations), minimum and maximum values of the desert dust layer parameters (base, top, thickness, and center of mass) which are listed only for stations which obtained more than three dust observations or had a ratio of observed to "model-forecasted" dust days greater than 5\% (cf. Figure 3) (14 of the 20 stations). This criterion is applied to eliminate data corresponding to a low number of observations.
This ensures that only significant dust observations are analyzed.

[31] It also has to be mentioned that the dust layer parameters provided in this paper are calculated from the aerosol backscattered coefficients at 351 or $355 \mathrm{~nm}$, after the dead time and the geometrical overlap corrections have been performed to the lidar signals [Weitkamp, 2005]. Therefore, only reliable data are provided in Table 2 (all numbers refer to heights above sea level (a.s.l.)).

[32] We can see from Table 2 that the core of the mean value of the dust layer (center of mass) typically stays around 3000-3800 m over the European continent, except over Barcelona and Lecce, where it is located around $2500 \mathrm{~m}$, and over NE Europe (Minsk), where it rises as high as $6000 \mathrm{~m}$. The dust layer thickness presents a much higher variability than its center of mass over S and SE Europe, since its mean value ranges from about $700 \mathrm{~m}$ (over Thessaloniki) 

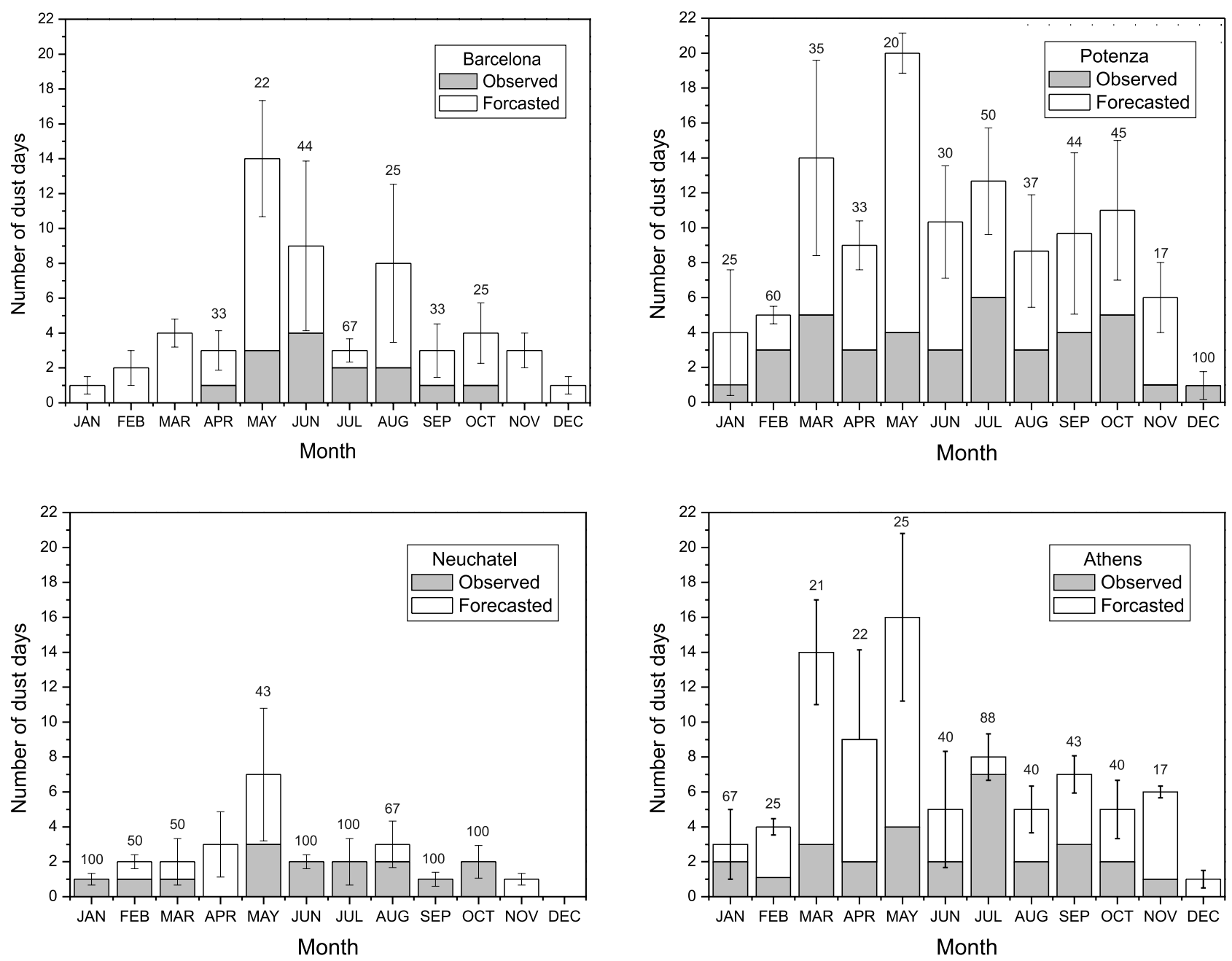

Figure 5. Mean number of dust days observed (gray column) and "model-forecasted" (white column) per month for four representative EARLINET stations (May 2000 to December 2002) (a) Barcelona (Spain), (b) Potenza (Italy), (c) Neuchâtel (Switzerland), and (d) Athens (Greece). The respective percentage (\%) of observed to forecasted number of days is also indicated at the top of each column. Error bars represent the standard deviation from the mean of the "model-forecasted" days per month.

up to $3340 \mathrm{~m}$ (over Potenza), without important latitude dependence. The mean values of the base and the top of the dust layer also show a large variability across Europe. The top mean value ranges from 3600 to $7200 \mathrm{~m}$, while the base mean value ranges from 1356 to $4700 \mathrm{~m}$. The corresponding individual values of the top of the dust layer range from 1100 to $10030 \mathrm{~m}$, while those of the dust layer base range from 490 to $7100 \mathrm{~m}$. Therefore, dust layer thickness varies from a few hundred to several thousand meters over most of the sites.

[33] Comparing the results from Table 2 and Figure 2b, we find a good agreement between the lidar observations and the DREAM model calculations, concerning the mean value of the maximum height of presence of dust particles which can reach even $7000 \mathrm{~m}$ in the geographical area located between 20 and $40^{\circ} \mathrm{E}$ (longitude) and $40-47^{\circ} \mathrm{N}$ (latitude) during spring time.

[34] The high variability of the dust layer parameters observed over the European continent reflects the natural variability of the Saharan dust intrusion process itself. It is evident that during summertime when the PBL height reaches its highest value [Matthias et al., 2004b] there are cases of dust intrusion inside the PBL especially for southern stations (i.e., over Italy, and Greece), thus leading to an abrupt increase of the aerosol concentration even near the ground level [Rodriguez et al., 2001; Vautard et al., 2005; Escudero et al., 2006; Gobbi et al., 2007].

\subsubsection{Dust Aerosol Optical Properties}

[35] The mean aerosol optical properties during Saharan dust transport were calculated for all dust days and separately for each station, in the time period under study. During daytime, only the aerosol backscatter $b_{\text {aer }}$ coefficient can be retrieved, using the Klett inversion technique [Klett, $1985]$ and in this case the uncertainty of the retrieved $b_{\text {aer }}$ vertical profile (including both statistical and systematic errors and corresponding to 30-60 min. temporal resolution) is of the order of 20-30\% [Böckmann et al., 2004]. This can be overcome by the nighttime Raman measurements, which can be used to retrieve the mean values of the aerosol backscatter $\mathrm{b}_{\mathrm{aer}}\left(\mathrm{in} \mathrm{m}^{-1} \mathrm{sr}^{-1}\right.$ ) and extinction 


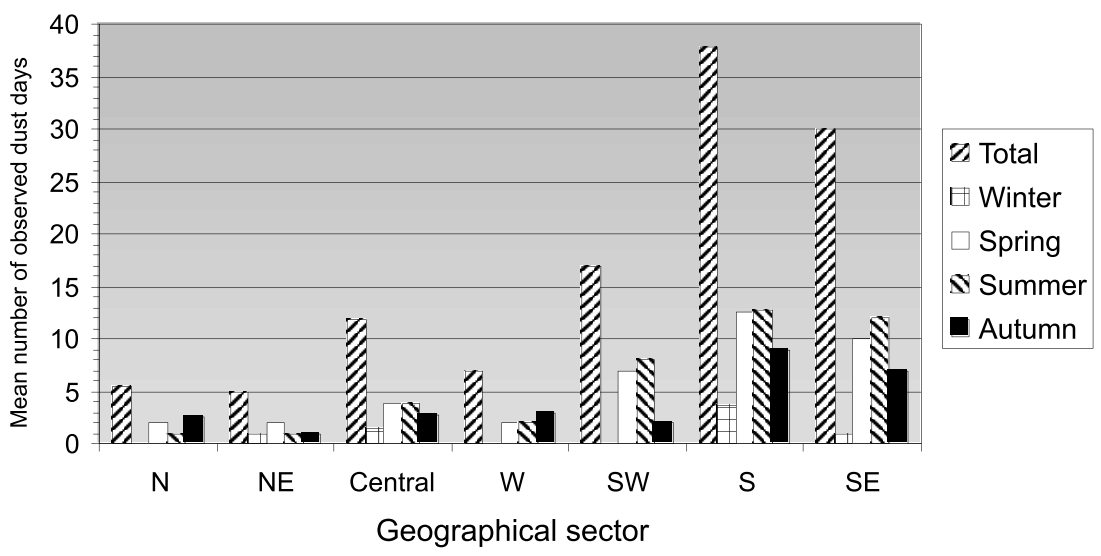

Figure 6. Seasonal variability of the observed mean number of Saharan dust days during EARLINET (May 2000 to December 2002) per sector over the European continent (north, northeastern, central, western, southwestern, south, and southeastern Europe).

$\mathrm{a}_{\mathrm{aer}}\left(\right.$ in $\mathrm{m}^{-1}$ ) coefficients, and the corresponding lidar ratio (sr) at 351 or $355 \mathrm{~nm}$ from ground up to altitudes generally higher than the dust layer (i.e., $7-8 \mathrm{~km}$ a.s.1.). The aerosol optical depth (AOD) was obtained by vertically integrating the aerosol extinction profile inside the Saharan dust layer.
The mean uncertainties of the retrieved $a_{a e r}$ and $b_{a e r}$ vertical profiles related to the Raman technique are of the order of 10-15\% [Mattis et al., 2002] in the PBL. Amiridis et al. [2005] found for $355 \mathrm{~nm}$ that in the free troposphere typical aerosol backscatter coefficient errors are below 30\% for
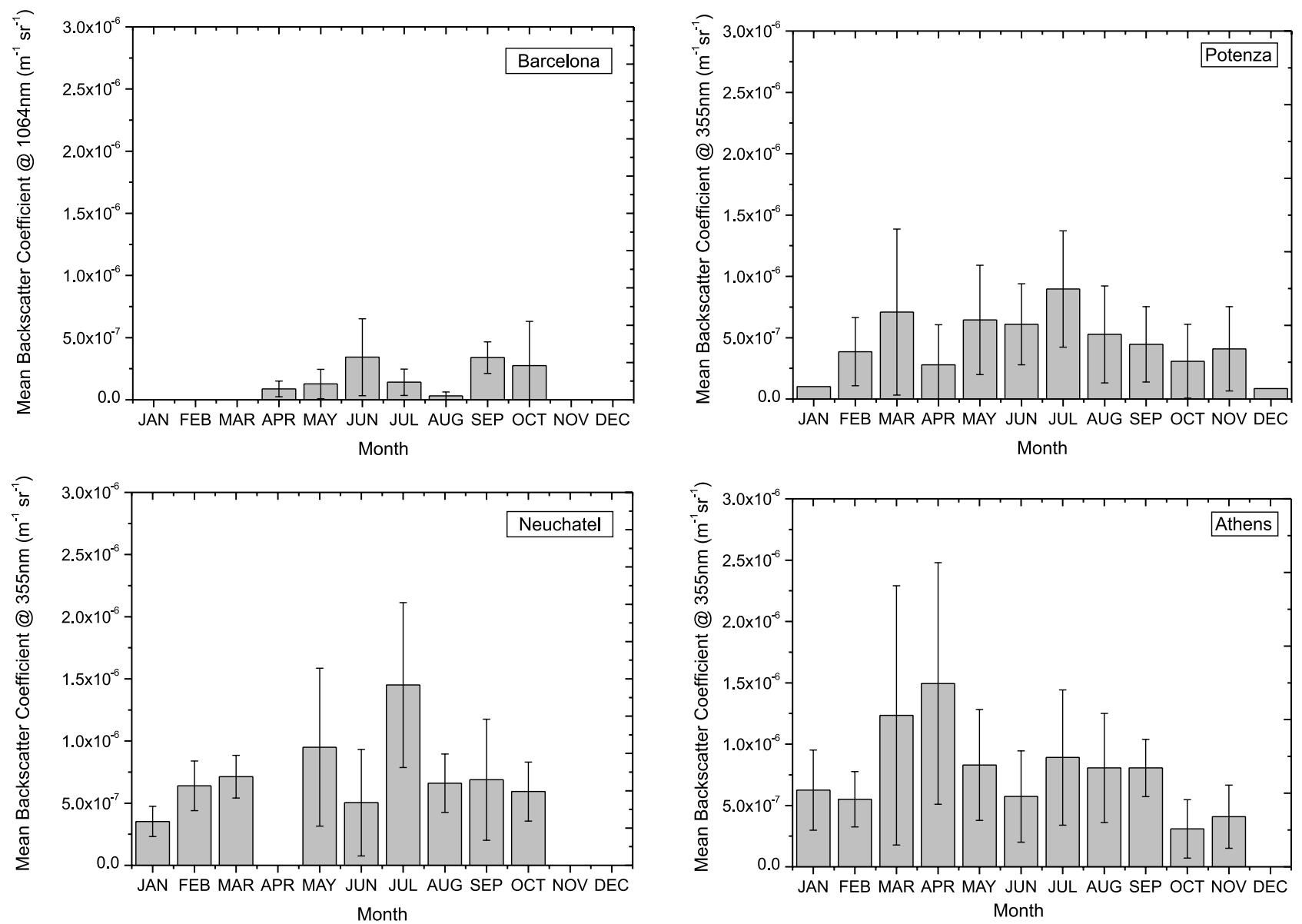

Figure 7. Mean values of the backscatter coefficient (with the relevant standard deviation) per month for the dust layers observed for four representative EARLINET stations (May 2000 to December 2002)

(a) Barcelona (Spain) (1064 nm), (b) Potenza (Italy) $(355 \mathrm{~nm})$, (c) Neuchâtel (Switzerland) (355 nm), and

(d) Athens (Greece) $(355 \mathrm{~nm})$. 
Table 2. Main Characteristics of the Saharan Dust Layer per Station Retrieved From the Aerosol Backscatter Profiles at $351 / 355 \mathrm{~nm}^{\mathrm{a}}$

\begin{tabular}{|c|c|c|c|c|c|c|c|c|}
\hline Station & $\begin{array}{c}\text { Base } \\
\text { Mean }(\mathrm{m}) \\
\end{array}$ & $\begin{array}{l}\text { Base Min, } \\
\text { Max (m) }\end{array}$ & $\begin{array}{c}\text { Top } \\
\text { Mean (m) }\end{array}$ & $\begin{array}{l}\text { Top Min, } \\
\text { Max (m) }\end{array}$ & $\begin{array}{l}\text { Thickness } \\
\text { Mean }(\mathrm{m})\end{array}$ & $\begin{array}{l}\text { Thickness Min, } \\
\text { Max (m) }\end{array}$ & $\begin{array}{c}\text { Center of mass } \\
\text { Mean }(\mathrm{m})\end{array}$ & $\begin{array}{l}\text { Center of mass } \\
\text { Min, Max (m) }\end{array}$ \\
\hline at & $2100 \pm 675$ & 1100,3000 & $4970 \pm 1305$ & 1900,8000 & $2154 \pm 817$ & 500,4800 & $3570 \pm 942$ & 1500,6500 \\
\hline ba & $1434 \pm 441$ & 850,3000 & $3608 \pm 1605$ & 1150,9000 & $2175 \pm 1165$ & 300,6000 & $2521 \pm 1023$ & 1000,6000 \\
\hline gp & $2060 \pm 1440$ & 730,5100 & $5162 \pm 1505$ & 2400,8500 & $2629 \pm 1733$ & 500,7470 & $3614 \pm 1333$ & 1500,6700 \\
\hline $\mathrm{kb}$ & $4033 \pm 1285$ & 2445,5545 & $5331 \pm 1067$ & 4035,6645 & $1297 \pm 353$ & 900,1600 & $4795 \pm 1382$ & 2995,6345 \\
\hline la & $2450 \pm 1100$ & 500,4000 & $3960 \pm 1050$ & 1100,6300 & $1520 \pm 756$ & 500,3500 & $3200 \pm 715$ & 1875,4625 \\
\hline lc & $1356 \pm 609$ & 492,2642 & $4087 \pm 1363$ & 1482,7272 & $2589 \pm 1070$ & 900,6060 & $2458 \pm 837$ & 854,4440 \\
\hline le & $1990 \pm 1077$ & 750,5500 & $4997 \pm 1796$ & 1710,10030 & $3284 \pm 1602$ & 700,7000 & $3849 \pm 1086$ & 2995,6340 \\
\hline $\mathrm{mi}$ & $4700 \pm 1600$ & 2400,7100 & $7200 \pm 1700$ & 3500,10000 & $2400 \pm 1500$ & 500,6000 & $6000 \pm 1500$ & 3000,8000 \\
\hline $\mathrm{mu}$ & $2450 \pm 1080$ & 1300,4800 & $4490 \pm 1020$ & 3200,6500 & $2040 \pm 920$ & 900,3600 & $3530 \pm 1270$ & 1500,5400 \\
\hline na & $1500 \pm 450$ & 600,5000 & $4500 \pm 900$ & 2100,9000 & $3000 \pm 950$ & 650,7100 & $3150 \pm 1000$ & 1100,6575 \\
\hline ne & $2940 \pm 540$ & 2040,3810 & $4350 \pm 660$ & 3180,6120 & $1740 \pm 540$ & 960,3660 & $3348 \pm 690$ & 2558,4508 \\
\hline $\mathrm{pl}$ & $2100 \pm 1100$ & 400,4000 & $4000 \pm 1000$ & 2300,6000 & $1800 \pm 1200$ & 300,4600 & $3100 \pm 900$ & 1500,4900 \\
\hline po & $2500 \pm 500$ & 1750,6100 & $5900 \pm 1200$ & 3100,8900 & $3340 \pm 1265$ & 840,6900 & $3467 \pm 631$ & 2300,6600 \\
\hline th & $2980 \pm 850$ & 1490,4310 & $3670 \pm 940$ & 2030,5330 & $726 \pm 271$ & 300,1170 & $3343 \pm 910$ & 1760,4820 \\
\hline
\end{tabular}

${ }^{a}$ The standard deviation of the mean values is also given.

values greater than about $0.1 \mathrm{Mm}^{-1} \mathrm{sr}^{-1}$. For the aerosol extinction coefficient, errors are below $30 \%$ in the free troposphere for values greater than about $5 \mathrm{Mm}^{-1}$ [Mona et al., 2006]. At the station of Leipzig, the linear depolarization ratio of dust could be also retrieved at $532 \mathrm{~nm}$ [Müller et al., 2003]. This parameter can be used to distinguish layers of spherical or nonspherical aerosol particles and, thus, to identify desert dust layers [Murayama et al., 1999].

[36] In Figures 7a to 7d, we present the monthly variation (with the relevant standard deviation) of the mean aerosol backscatter coefficient for the four selected and representative sites which have more than $40 \mathrm{~d}$ of dust observations. The mean values presented here were calculated for the dust layer heights for each station. The mean aerosol backscatter coefficients measured over Barcelona were obtained at 1064 $\mathrm{nm}$, while the data given for the other stations (Potenza, Neuchâtel, and Athens) were obtained at $355 \mathrm{~nm}$. Therefore, the values of the mean aerosol backscatter coefficient are generally lower over Barcelona $\left(<0.5 \mathrm{Mm}^{-1} \mathrm{Sr}^{-1}\right)$ than over the other sites $\left(<1-1.5 \mathrm{Mm}^{-1} \mathrm{sr}^{-1}\right)$. The maximum mean aerosol backscatter coefficient values are observed mainly in spring over Athens $\left(1.5 \mathrm{Mm}^{-1} \mathrm{sr}^{-1}\right)$ and mostly during the summer period over the other stations (1$\left.1.5 \mathrm{Mm}^{-1} \mathrm{sr}^{-1}\right)$. Secondary maxima $\left(0.5-1 \mathrm{Mm}^{-1} \mathrm{sr}^{-1}\right)$ are found during autumn and spring (e.g., Barcelona, Potenza, and Neuchâtel) or summer (e.g., Athens) periods. Again as in the case of the measurement days the lidar observations roughly follow the annual cycle predicted by the dust model.

[37] Figure 8 gives the mean vertical profiles of the aerosol extinction (left) and backscatter coefficient (middle) and the corresponding lidar ratio together with its standard deviation (right) in the period studied for the eight lidar stations (at, kb, la, lc, le, na, po, th) which are equipped with a nitrogen $\left(\mathrm{N}_{2}\right)$ ultraviolet (UV) Raman channel (the Raman wavelengths available are $387 \mathrm{~nm}$ (using the $355 \mathrm{~nm}$ laser excitation wavelength) and $382 \mathrm{~nm}$ (using the $351 \mathrm{~nm}$ laser excitation wavelength)). The number of the averaged nighttime LR profiles is also given in parenthesis inside Figure 8's legend (right). The data were first binned in the vertical into $500 \mathrm{~m}$ layers and the final mean profiles were calculated by the individual profiles for the Saharan dates reported by each station.

[38] The presence of distinct Saharan dust layers is not obvious from the mean extinction or backscatter profiles (except in some cases) since the height interval of those layers in the individual profiles was variable. Average extinction and backscatter profiles show small latitude dependence, especially in low altitudes. Above $4 \mathrm{~km}$ the aerosol extinction over northern stations (Leipzig) is comparable to or even higher than that of some southern stations (e.g., Napoli). In general, the closer the observing site is to the dust source region, the higher is the corresponding aerosol extinction coefficient. However, since only the intense dust outbreaks can reach the higher latitudes (central and northern Europe) the corresponding extinction profiles over northern stations can be higher than those of southern or in some cases of the central stations, where dust outbreaks of variable intensity can be recorded, thus affecting the mean extinction profile. The backscatter coefficient profiles presented in Figure 8 (middle) show, in general, higher values $\left(>4 \mathrm{Mm}^{-1} \mathrm{sr}^{-1}\right)$ over the southern stations than over the northern stations.

[39] Considering the mean lidar ratio profiles for the different sites (Figure 8, right), one can see that this parameter ranges between 20 and $90 \mathrm{sr}$, showing greater variability mainly above $2500 \mathrm{~m}$ for all stations. The lidar ratio depends on the shape and the size characteristics of the backscattering particles and, therefore, also on the aerosol mixing processes (mixing of dust, maritime, and anthropogenic particles). The influence of mixing is clearly indicated by the lidar ratio profiles of Athens and Lecce. The lidar ratio increases from 25 to $50 \mathrm{sr}$ below $2500 \mathrm{~m}$ height, where aerosol mixing processes occur, up to $85-90 \mathrm{sr}$ inside the pure dust layer (typically above $2500 \mathrm{~m}$ ).

[40] The main conclusions from Figure 8 are (1) care has to be taken in the interpretation of optical properties measured in dust layers below $2500 \mathrm{~m}$ where mixing can occur, (2) the top of most dust layers is at about 5000 to $6000 \mathrm{~m}$ height (see also Table 2), (3) typical Saharan dust extinction coefficients range from 50 to $200 \mathrm{Mm}^{-1}$, and (4) LR typical values range from about 40 to $90 \mathrm{sr}$ in the Saharan dust layers above $2500 \mathrm{~m}$. These values can be reproduced by simulations in which dust particles are assumed to be spheroids [Dubovik et al., 2006].

[41] To further investigate the variability of the lidar ratio, we concentrated our study on three selected Raman lidar stations that also performed additional elastic backscatter measurements at 532 or $1064 \mathrm{~nm}$. The calculated profiles of the particle backscatter coefficient at two wavelengths ( $w l_{1}$ 


\section{Raman nighttime measurements at $351 / 355 \mathrm{~nm}$}

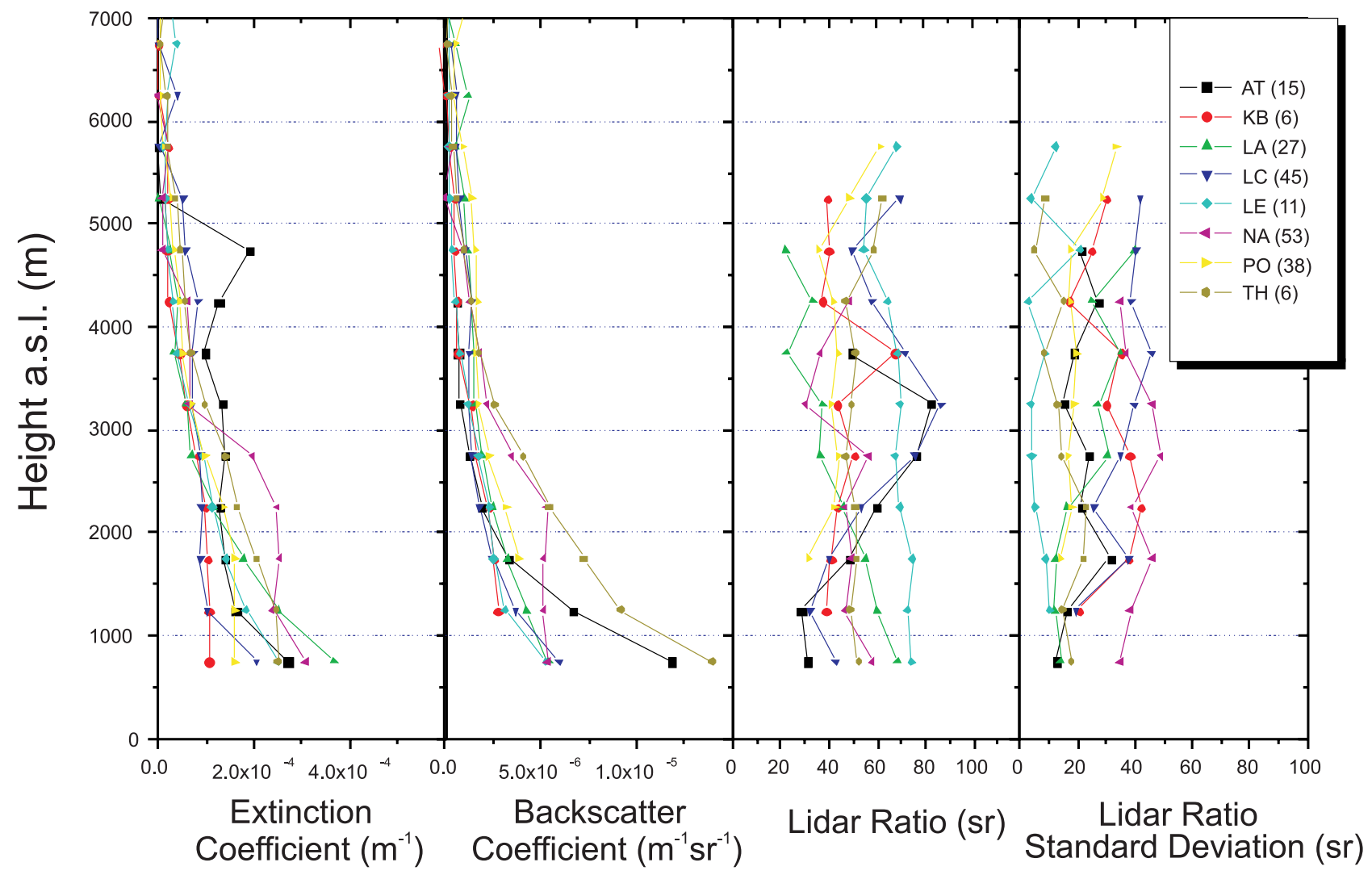

Figure 8. Mean vertical profiles of the aerosol extinction coefficient $\left(\right.$ in $\mathrm{m}^{-1}$ ), backscatter coefficient (in $\mathrm{m}^{-1} \mathrm{sr}^{-1}$ ) and the corresponding lidar ratio (in $\mathrm{sr}$ ) at $351 / 355 \mathrm{~nm}$ along with lidar ratio standard deviation for all Saharan dust days, per station. The number of averaged profiles is denoted in the legend.

and $w l_{2}$ ) allow us also to determine the backscatter-related Ångström exponent (BRAE), defined as:

$$
\operatorname{BRAE}(z)=-\ln \left(b^{w l_{1}}(z) / b^{w l_{2}}(z)\right) / \ln \left(w l_{1} / w l_{2}\right)
$$

[42] In Figure 9 we present the BRAE and lidar ratio measurements for all the Saharan dust cases, performed over the Potenza (Figure 9a), Thessaloniki (Figure 9b), and Leipzig (Figure 9c) stations along with the mean profile of each parameter for each station. Error bars indicate the corresponding standard deviations. For the Leipzig station the LR profiles refer to $532 \mathrm{~nm}$, and the corresponding BRAE profiles were calculated from the backscatter coefficients at 532 and $1064 \mathrm{~nm}$, since at this station more observations were available at the visible than the ultraviolet Raman channels. For the considered period, Leipzig is the only EARLINET lidar station that performed lidar measurements at both 355 and $532 \mathrm{~nm}$ and the corresponding Raman channels (387 and $607 \mathrm{~nm}$ ), and the elastic backscatter signal was simultaneously recorded at 355, 532, $1064 \mathrm{~nm}$ [Mattis et al., 2002].

[43] For the Leipzig station one can observe in Figure 9 (lowest graph) that the variability of the BRAE and lidar ratio values is the smallest in comparison with the other stations. The Leipzig station is the most northern one of the three stations selected in Figure 9. The mean LR was found equal to $59 \pm 11 \mathrm{sr}$ at $532 \mathrm{~nm}$ and $65 \pm 12 \mathrm{sr}$ at $355 \mathrm{~nm}$. The LR values averaged here refer to major dust outbreaks. According to the data analysis of the Leipzig station results, there is an indication that the lidar ratio of dust at $355 \mathrm{~nm}$ is about $10 \%$ higher than at $532 \mathrm{~nm}$. These LR values correspond to BRAE of $0.5 \pm 0.21$, indicating relatively large dust particles.

[44] A greater variability of the BRAE values was observed for the Potenza station (Figure 9 upper graph), probably caused by the high number of observed dust cases of weak, moderate, and major dust outbreaks and the variability of aerosol microphysical properties, due to differences in dust composition and modification and mixing processes occurring during the transport. For this station the mean LR at $355 \mathrm{~nm}$ was equal to $38 \pm 15 \mathrm{sr}$, while the mean BRAE value was found equal to $1.5 \pm 0.6$. A detailed analysis of the frequency distribution of the LR values recorded for Saharan dust observations over Potenza [Mona et al., 2006] revealed us to find out that LR values around $20 \mathrm{sr}$ are related in some cases to mixing of dust with maritime particles, as it is well documented that maritime particles cause lidar ratios around 20 sr [Ackermann, 1998; Müller et al., 2007].

[45] The Thessaloniki station (Figure 9, middle) also showed a great variability in the lidar ratio and BRAE values and the corresponding mean values were $45 \pm 20 \mathrm{sr}$ for the LR at $355 \mathrm{~nm}$ and $1.4 \pm 0.5$ for the BRAE. Owing to 

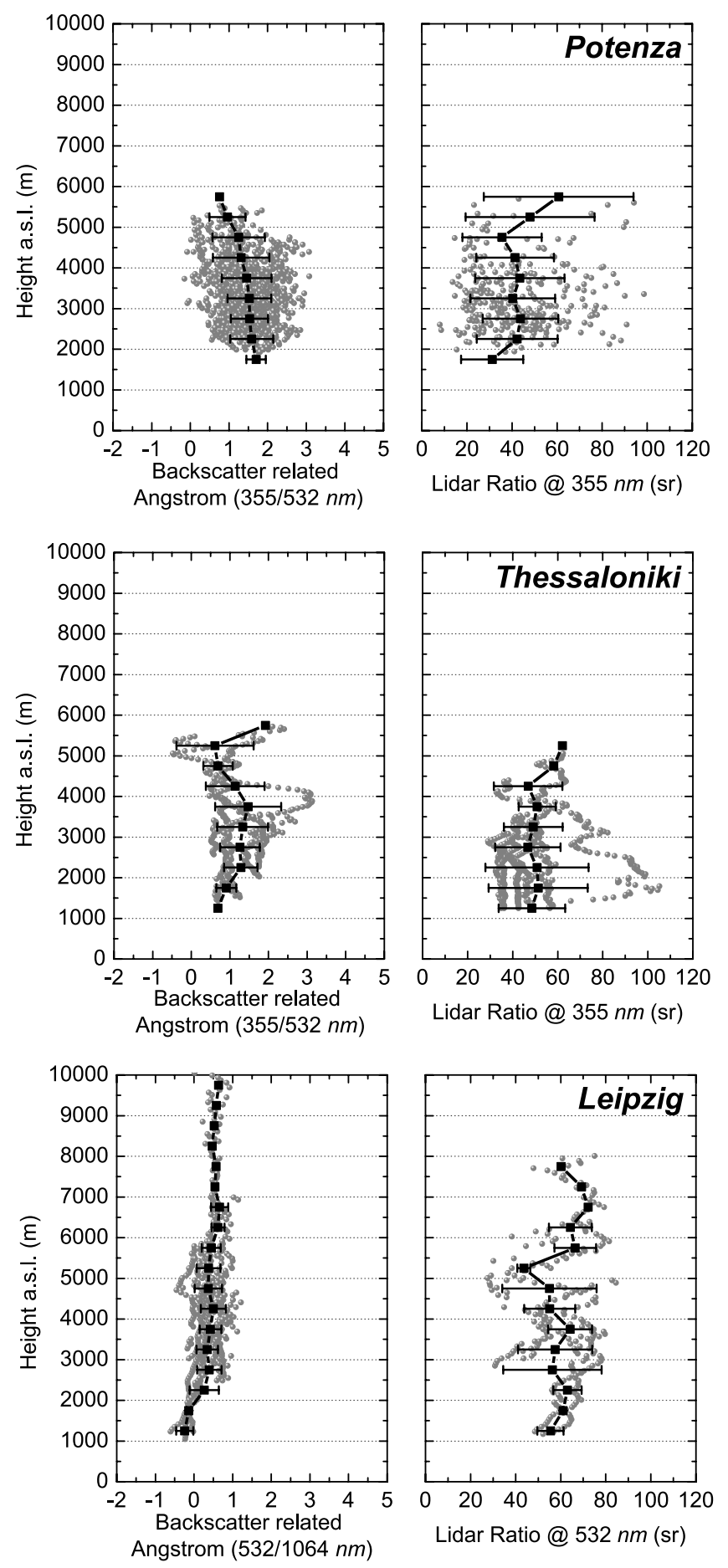

Figure 9. BRAE and LR vertical profiles for all the Saharan dust cases, obtained over (a) Potenza, (b) Thessaloniki, and (c) Leipzig, along with the mean profile of each parameter for each station. Error bars indicate standard deviations.

the proximity of the southern European stations to the Sahara region, in many cases dust layers are not well separated from locally produced anthropogenic particles, mainly inside the PBL. In many cases, an aerosol layer is distinguishable above the PBL and it is clearly related to Saharan dust outbreaks, but mixing processes with local aerosol are highly probable as well, especially in the lower free troposphere.

[46] BRAE values less than 1.0 indicate the presence of relatively large, probably nonspherical particles. The large LR values that correspond to these low values of BRAE in Figure 9 can be explained by the deviations between the scattering characteristics of spheres and nonspherical particles. Model calculations assume spherical particles, while the nonspherical shape of the desert particles can lead to a strong reduction in the backscattering efficiency compared with backscattering by surface-equivalent spheres [Mishchenko et al., 1997; Mattis et al., 2002]. This behavior results in large LR values.

[47] BRAE values exceeding 1.0 indicate the presence of smaller particles. LR values corresponding to BRAE values greater than 1.0 showed large variability and a tendency to smaller values. Smaller LR values can also be explained by the shape effect, since the nonsphericity becomes less important in the case of smaller mean particle size [Gobbi et al., 2002; Müller et al., 2003]. This is consistent with our measurements of the LR and the BRAE.

[48] BRAE values greater than 2.0 (cf. Figure 9) indicate the dominance of smaller particles, too small to represent desert dust and possibly related to air pollution. The corresponding LR values show less variability and a tendency to smaller values, mainly less than $40 \mathrm{sr}$, reaching values even less than $20 \mathrm{sr}$. In their study for the station of Thessaloniki, Balis et al. [2004] found similar unusual results for desert dust, although, according to the DREAM model, significant dust load has been estimated for the corresponding days. They attributed the large BRAE values to the fact that most of the mineral particles had already been removed and replaced by anthropogenic particles as a result of the upward mixing of air pollution. The corresponding small lidar ratios were attributed to mixing processes with sea-salt aerosols, which in general are characterized by small lidar ratio values. Consistent results with the study of Balis et al. [2004] were recently published also by Mona et al. [2006] for the Potenza station.

[49] In Figure 10 we present the mean AOD (upper graph) and LR (lower graph) values at $355 \mathrm{~nm}$ only inside the clearly identified dust layer region (above $2500 \mathrm{~m}$ height), plotted as a function of the distance of a station to the Sahara area for the UV Raman lidar stations. The mean LR values ranged between 38 and $60 \mathrm{sr}$ inside the dust layer, while their standard deviation is of the order of $20-30 \%$. On the other hand, the mean AOD values ranged between 0.1 and 0.25 with a standard deviation of the order of $20-100 \%$ inside the dust layer, which clearly indicates the high variability of the dust outbreaks over Europe. It is interesting that both the LR and AOD values do not show a significant dependence on the distance from the Saharan desert.

\section{Conclusions and Discussion}

[50] A 32-month analysis of Saharan dust observations and the characteristics and optical properties of the desert aerosols detected over the European continent are presented, extending some individual EARLINET studies which had been previously performed for southern Italy and Greece [Balis et al., 2004; Papayannis et al., 2005; Mona et al., 


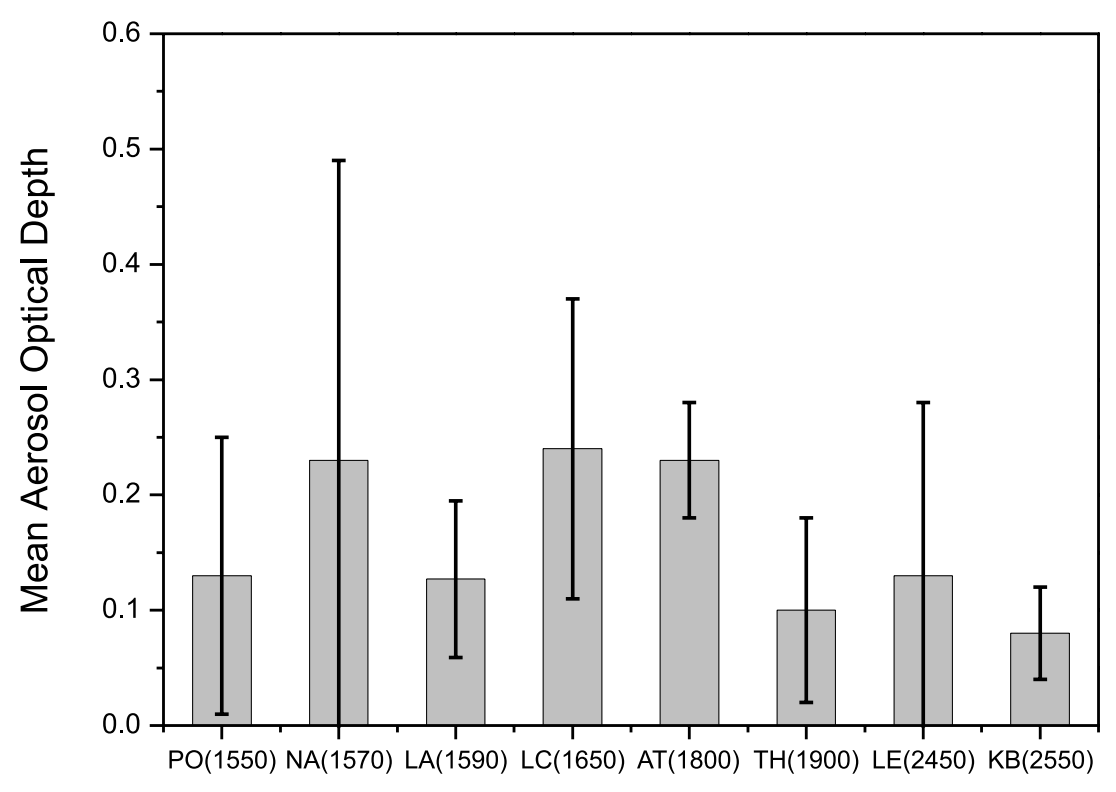

EARLINET Station

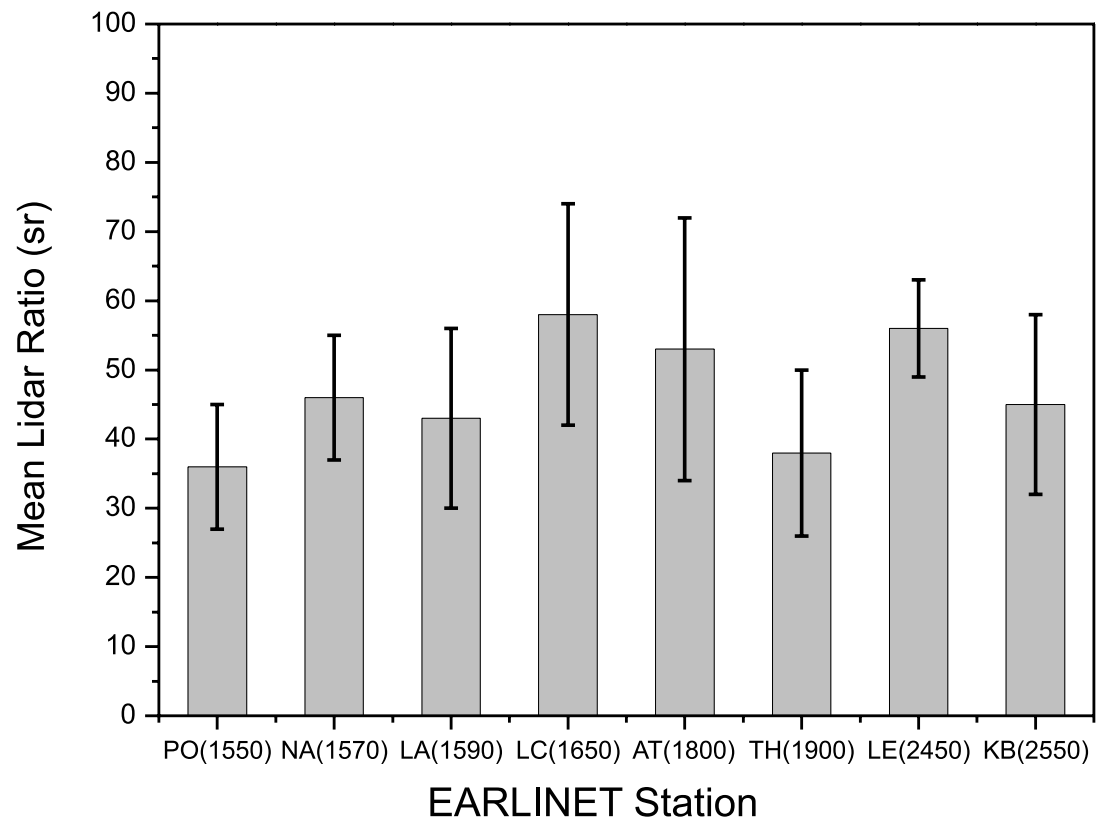

(b)

Figure 10. Mean AOD (upper graph) and mean LR (lower graph) together with the corresponding standard deviation, calculated inside the dust layers, per EARLINET station equipped with a Raman lidar system as a function of distance from the Saharan region (the numbers in parenthesis indicate the distance in $\mathrm{km}$ of the station from the Saharan region).

2006; Balis et al., 2006]. This effort is currently continued in the framework of the European Aerosol Research Lidar Network-Advanced Sustainable Observation System (EARLINET-ASOS) project (2006-2011). At present, this is the longest analysis of vertical profiles of Saharan dust optical properties on a continental scale, yielding the study of the horizontal and vertical extent of dust outbreaks over Europe. The aerosol dust properties were acquired using ultraviolet elastic and Raman lidar systems at 351 or $355 \mathrm{~nm}$.
[51] During the reported period (May 2000 to December 2002) more than 70 events of Saharan dust outbreaks over Europe were monitored. Multiple aerosol layers of variable thickness (mean value ranges from 1500 to $3400 \mathrm{~m}$ ) were observed in the altitudes between 1100 and $9000 \mathrm{~m}$ a.s.l. Traces of dust particles reached heights up to $10000 \mathrm{~m}$, after a 2-5 d transport from the source region. Most episodes were recorded during the late spring, summer, and early autumn months, while fewest were observed during the winter period. In most of cases the episodes lasted from 1 to 
$5 \mathrm{~d}$, while very few lasted even up to $7-10 \mathrm{~d}$. The mean number of dust episodes observed per season is much higher in the southern and southeastern European regions, due to the prevailing meteorological conditions (direction of wind flow) in conjunction with their vicinity to the Sahara desert.

[52] The general conclusion derived from the cluster analysis performed is that three main Saharan dust source regions play a key role in the dust transport to Europe in the height region between 3 and $5 \mathrm{~km}$ : the WS, the CS, and the ES regions. Western Europe seems to be mostly affected by the WS source area, and the central and northern European regions seem to be mostly affected by WS and CS source areas, respectively. Finally, the southern and southeastern European regions seem to be mostly affected by CS and ES source regions. Our observations have also shown that Saharan dust aerosols can penetrate deeply into central and eastern Europe (even up to $60^{\circ} \mathrm{N}$ and $30^{\circ} \mathrm{E}$ ), where they may still coexist with clouds [Ansmann et al., 2003].

[53] During the reported period, typical Saharan dust backscatter coefficients over Europe ranged from 0.5 to $1.5 \mathrm{Mm}^{-1} \mathrm{sr}^{-1}$ inside the dust layer. The mean AOD values ranged from 0.1 to 0.25 (at 355 or $351 \mathrm{~nm}$ ), while the mean lidar ratio values ranged from 30 to $80 \mathrm{sr}$ within the lofted dust plumes. In some cases at the southern and northern European stations LRs higher than 50 sr were found which were similar or higher to the ones found for Asian dust [Sakai et al., 2002]. These LR values are higher than those obtained by theoretical estimations for spherical dust particles [Ackermann, 1998]. In northern Europe approximately constant BRAE values ( -0.5 to 1$)$ and high LR values ( 30 to $80 \mathrm{sr}$ ) were found during the Saharan dust outbreaks. In southern and southeastern Europe a high LR (20 to $100 \mathrm{sr})$ and BRAE ( -0.5 to 3 ) variability was found mostly related to the variability of aerosol microphysical properties, due to differences in dust composition, and modification and mixing processes occurred during the transport from the source region.

[54] The large variability observed on the LR values between the different sites can be related to the existing differences in shape and dimension of the dust particles [Mishchenko et al., 1997] apart from their probable mixing with maritime and anthropogenic aerosols along their trajectory from the source region to the observation site. Linear depolarization ratios of aerosols within the dust plume ranged from 10 to $25 \%$ at $532 \mathrm{~nm}$ over northern Europe.

[55] Our analysis of the lidar data for the first time allowed us to estimate simultaneously the dust aerosol optical properties and the dust layer characteristics at a horizontal and vertical extent over Europe during a 32-month period. This information can be used as an important input into radiative transfer models (RTM) and atmospheric chemistry transport models (ACTM), since it is well known that the inclusion of mineral dust profiles together with their radiative effects can lead to a significant improvement in the radiation balance computed with numerical weather prediction models, with subsequent improvements in the weather forecast itself [Stier et al., 2005; Pérez et al., 2006b].

[56] In addition, these observations can be very useful to improve satellite aerosol retrieval algorithms, as for instance the spaceborne lidar mission Cloud-Aerosol Lidar and Infrared Pathfinder Satellite Observations
(CALIPSO), especially by providing the LR values inside the dust layer [Winker et al., 2002; Huang et al., 2007; Winker et al., 2007] or to provide input to other satellite sensors (such as GOME, OMI, SCIAMACHY, etc.) and reduce the aerosol interference in the retrieved vertical profile of several atmospheric gases (e.g., $\mathrm{O}_{3}, \mathrm{NO}_{2}$, etc.) [Al-Saadi et al., 2005]. More specifically for the CALIPSO mission, where a simple backscatter lidar is operated, the provision of the LR values inside the dust layer is of fundamental importance for the subsequent retrieval of the aerosol extinction coefficients.

[57] Acknowledgments. This work was supported by the Environment Program of the European Union (EARLINET project) and the 6th Framework EU program (EARLINET-ASOS project) under contracts EVR1-CT1999-40003 and RICA-025991, respectively, as well as by the German Federal Ministry for Education and Research (ATMOFAST project). We acknowledge the German Weather Service (DWD) for the air mass back-trajectories analysis. Additional air mass back trajectories were produced with the Hybrid Single-Particle Lagrangian Integrated Trajectory (HYSPLIT-4.6) model (NOAA). The cluster analysis algorithm was kindly provided by José Baldasano (Universitat Politécnica de Catalunya, Spain). We also acknowledge G. Vaughan for providing lidar data from the Aberystwyth (UK) site. The three reviewers of the paper are gratefully acknowledged for their comments and recommendations.

\section{References}

Ackermann, J. (1998), The extinction-to-backscatter ratio of tropospheric aerosol: A numerical study, J. Atmos. Ocean. Technol., 15, 1043-1050, doi:10.1175/1520-0426(1998)015<1043:TETBRO>2.0.CO;2.

Al-Saadi, J., et al. (2005), Improving national weather forecasts with satellite aerosol observations, Bull. Am. Meteorol. Soc., 86, 1249-1261, doi:10.1175/BAMS-86-9-1249.

Amiridis, V., D. S. Balis, S. Kazadzis, A. Bais, E. Giannakaki, A. Papayannis, and C. Zerefos (2005), Four-year aerosol observations with a Raman lidar at Thessaloniki, Greece, in the framework of European Aerosol Research Lidar Network (EARLINET), J. Geophys. Res., 110, D21203, doi:10.1029/2005JD006190.

Ansmann, A., M. Riebesell, U. Wandinger, C. Weitkamp, E. Voss, W. Lahmann, and W. Michaelis (1992), Combined Raman elastic-backscatter lidar for vertical profiling of moisture, aerosol extinction, backscatter and lidar ratio, Appl. Phys. B, 55, 18-28, doi:10.1007/BF00348608.

Ansmann, A., et al. (2003), Long-range transport of Saharan dust to northern Europe: The $11-16$ October 2001 outbreak observed with EARLINET, J. Geophys. Res., 108(D24), 4783doi:10.1029/2003JD003757.

Antoine, D., and D. Nobileau (2006), Recent increase of Saharan dust transport over the Mediterranean Sea as revealed from ocean color satellite (SeaWiFS) observations, J. Geophys. Res., 111, D12214, doi:10.1029/2005JD006795.

Balis, D., V. Amiridis, S. Nickovic, A. Papayannis, and C. Zerefos (2004), Optical properties of Saharan dust layers as detected by a Raman lidar at Thessaloniki, Greece, Geophys. Res. Lett., 31, L13104, doi:10.1029/ 2004GL019881

Balis, D., et al. (2006), Optical characteristics of desert dust over the East Mediterranean during summer: A case study, Ann. Geophys., 24, 807821.

Barkan, J., P. Alpert, H. Kutiel, and P. Kishcha (2005), Synoptics of dust transportation days from Africa toward Italy and central Europe, J. Geophys. Res., 110, D07208doi:10.1029/2004JD005222.

Barnaba, F., and G. P. Gobbi (2004), Aerosol seasonal variability over the Mediterranean region and relative impact of maritime, continental and Saharan dust particles over the basin from MODIS data in the year 2001, Atmos. Chem. Phys., 4, 2367-2391.

Böckmann, C., et al. (2004), Aerosol lidar intercomparison in the framework of the EARLINET project. 2. Aerosol backscatter algorithms, Appl. Opt., 43, 977-989, doi:10.1364/AO.43.000977.

Bösenberg, J., et al. (2003), A European aerosol research lidar network to establish an aerosol climatology, MPI-Rep. 317, Max-Planck Inst. für Meteorol., Hamburg, Germany.

Carnuth, W., U. Kempfer, and T. Trickl (2002), Highlights of the tropospheric lidar studies at IFU within the TOR Project, Tellus, Ser. B, 54, 163-185, doi:10.1034/j.1600-0889.2002.00245.x.

Chiapello, I., G. Bergametti, B. Chatenet, P. Bousquet, F. Dulac, and E. Santos Soares (1997), Origins of African dust transported over the northeastern tropical Atlantic, J. Geophys. Res., 102, 13,701-13,709, doi:10.1029/97JD00259. 
Dayan, U., J. Heffter, J. Miller, and G. Gutman (1991), Dust intrusion events into the Mediterranean basin, J. Appl. Meteorol., 30, $1185-$ 1199, doi:10.1175/1520-0450(1991)030<1185:DIEITM >2.0.CO;2.

De Tomasi, F., A. Blanco, and M. R. Perrone (2003), Raman lidar monitoring of extinction and backscattering of African dust layers and dust characterization, Appl. Opt., 42, 1699-1709, doi:10.1364/AO.42. 001699.

di Sarra, A., T. di Iorio, M. Cacciani, G. Fiocco, and D. Fua (2001), Saharan dust profiles measured by lidar at Lampedusa, J. Geophys. Res., 106, 10,335-10,348, doi:10.1029/2000JD900734.

Dorling, S., T. Davies, and C. Pierce (1992), Cluster analysis: A technique for estimating the synoptic meteorological controls on air and precipitation chemistry-Method and applications, Atmos. Environ., A26, $2575-$ 2581.

Draxler, R. R., and G. D. Hess (1998), An overview of the Hysplit 4 modeling system for trajectories, dispersion, and deposition, Aust. Meteorol. Mag., 47, 295-308.

Dubovik, O., et al. (2006), Application of spheroid models to account for aerosol particle non sphericity in remote sensing of desert dust, J. Geophys. Res., 111, D11208, doi:10.1029/2005JD006619.

Duce, R. A. (1995), Sources, distribution and fluxes of mineral aerosols and their relationship to climate, in Aerosol Forcing on Climate, edited by R. J. Carlson and J. Heintzenberg, pp. 43-72, John Wiley, New York.

Dulac, F., and P. Chazette (2003), Airborne study of a multi-layer aerosol structure in the eastern Mediterranean observed with the airborne polarized lidar ALEX during the STAAARTE campaign (7 July 1997), Atmos. Chem. Phys., 3, 1817-1831.

Dulac, F., P. Buat-Ménard, D. Sutton, D. Tanré, G. Bergametti, and M. Debois (1992), Assessment of the African airborne dust mass over the Western Mediterranean Sea using Meteosat data, J. Geophys. Res., 97, 2,489-2,506, doi:10.1029/91JD02427.

Dunion, J., and C. Velden (2004), The impact of the Saharan air layer on Atlantic tropical cyclone activity, Bull. Am. Meteorol. Soc., 85, 353-365, doi:10.1175/BAMS-85-3-353.

Engelstaedter, S., and R. Washington (2007), Temporal controls on global dust emissions: The role of surface gustiness, Geophys. Res. Lett., 34, L15805doi:10.1029/2007GL029971.

Escudero, M., A. Stein, R. R. Draxler, X. Querol, A. Alastuey, S. Castillo, and A. Avila (2006), Determination of the contribution of northern Africa dust source areas to $\mathrm{PM}_{10}$ concentrations over the central Iberian Peninsula using the Hybrid Single-Particle Lagrangian Integrated Trajectory model (HYSPLIT) model, J. Geophys. Res., 111, D06210, doi:10.1029/ 2005JD006395.

Forster, P., et al. (2007), Changes in atmospheric constituents and in radiative forcing, in Climate Change 2007: The Physical Science Basis. Contribution of Working Group I to the Fourth Assessment Report of the Intergovernmental Panel on Climate Change, edited by S. Solomon et al., pp. 129-234, Cambridge Univ. Press, New York.

Gobbi, G. P., F. Barnaba, R. Giorgi, and A. Santacasa (2000), Altituderesolved properties of a Saharan dust event over the Mediterranean, Atmos. Environ., 34, 5119-5127, doi:10.1016/S1352-2310(00)00194-1.

Gobbi, G. P., F. Barnaba, F. Blumthaler, M. Labow, and J. R. Herman (2002), Observed effects of particles non-sphericity on the retrieval of marine and desert dust aerosol optical depth by lidar, Atmos. Res., 61, 1-14, doi:10.1016/S0169-8095(01)00104-1.

Gobbi, G. P., F. Barnaba, and L. Ammannato (2004), The vertical distribution of aerosols, Saharan dust and cirrus clouds in Rome (Italy) in the year 2001, Atmos. Chem. Phys., 4, 351-359.

Gobbi, G. P., F. Barnaba, and L. Ammannato (2007), Estimating the impact of Saharan dust on the year $2001 \mathrm{PM}_{10}$ record of Rome, Italy, Atmos. Environ., 41, 261-275, doi:10.1016/j.atmosenv.2006.08.036.

Hamonou, E., P. Chazette, D. Balis, F. Dulac, X. Schneider, E. Galani, G. Ancellet, and A. Papayannis (1999), Characterization of the vertical structure of Saharan dust export to the Mediterranean basin, J. Geophys. Res., 104, 22,257-22,270, doi:10.1029/1999JD900257.

Holben, B. N., et al. (2001), An emerging ground-based aerosol climatology: Aerosol optical depth from AERONET, J. Geophys. Res., 106, 12,067-12,098, doi:10.1029/2001JD900014.

Huang, J., P. Minnis, Y. Yi, Q. Tang, X. Wang, Y. Hu, Z. Liu, K. Ayers, C. Trepte, and D. Winker (2007), Summer dust aerosols detected from CALIPSO over the Tibetan Plateau, Geophys. Res. Lett., 34, L18805, doi:10.1029/2007GL029938.

Intergovernmental Panel on Climte Change (2001), Climate Change 2001: The Scientific Basis, Contribution of Working Group I to the Third Assessment Report of the Intergovernmental Panel on Climate Change (IPCC), edited by J. T. Houghton et al., 881 pp., Cambridge Univ. Press, New York.

Kinne, S., et al. (2006), AeroCom initial assessment: Optical properties in aerosol component modules of global models, Atmos. Chem. Phys., 6, $1815-1834$.
Klett, J. D. (1985), Lidar inversion with variable backscatter to extinction ratios, Appl. Opt., 24, 1638-1643.

Levin, Z., E. Ganor, and V. Gladstein (1996), The effects of desert particles on with sulphate on rain formation in the Eastern Mediterranean, J. Appl. Meteorol., 35, 1511-1523, doi:10.1175/1520-0450(1996)035 $<1511$ :TEODPC $>2.0 . \mathrm{CO} ; 2$.

Levin, Z., A. Teller, E. Ganor, and Y. Yin (2005), On the interactions of mineral dust, sea-salt particles and clouds: A measurement and modelling study from the Mediterranean Israeli Dust Experiment campaign, J. Geophys. Res., 110, D20202, doi:10.1029/2005JD005810.

Marticorena, B., G. Bergametti, B. Aumont, Y. Callot, C. N'Doumé, and M. Legrand (1997), Modeling the atmospheric dust cycle: 2. Simulation of Saharan sources, J. Geophys. Res., 102, 4387-4404, doi:10.1029/ 96JD02964

Matthias, V., et al. (2004a), Aerosol lidar intercomparison in the framework of the EARLINET project: 1. Instruments, Appl. Opt., 43, 961-976, doi:10.1364/AO.43.000961.

Matthias, V., et al. (2004b), Vertical aerosol distribution over Europe: Statistical analysis of Raman lidar data from 10 European Aerosol Research Lidar Network (EARLINET) stations, J. Geophys. Res., 109, D18201, doi:10.1029/2004JD004638.

Mattis, I., A. Ansmann, D. Müller, U. Wandinger, and D. Althausen (2002), Dual-wavelength Raman lidar observations of the extinction-to-backscatter ratio of Saharan dust, Geophys. Res. Lett., 29(9), 1306, doi:10.1029/ 2002GL014721.

Miller, R., I. Tegen, and J. Perlwitz (2004), Surface radiative forcing by soil dust aerosols and the hydrologic cycle, J. Geophys. Res., 109, D04203, doi:10.1029/2003JD004085.

Mishchenko, M. I., L. D. Travis, R. A. Kahn, and R. A. West (1997), Modeling phase functions for dustlike tropospheric aerosols using a shape- mixture of randomly oriented polydisperse spheroids, J. Geophys. Res., 102, 16,831-16,847, doi:10.1029/96JD02110.

Mona, L., A. Amodeo, M. Pandolfi, and G. Pappalardo (2006), Saharan dust intrusions in the Mediterranean area: Three years of Raman lidar measurements, J. Geophys. Res., 111, D16203, doi:10.1029/2005JD006569.

Moulin, C., C. E. Lambert, F. Dulac, and U. Dayan (1997a), Control of atmospheric export of dust from North America by the North Atlantic Oscillation, Nature, 387, 691-694, doi:10.1038/42679.

Moulin, C., F. Dulac, C. E. Lambert, P. Chazette, I. Jankowiak, B. Chatenet, and F. Lavern (1997b), Long-term daily monitoring of Saharan dust load over ocean using Meteosat ISCCP-B2 data: 2. Accuracy of the method and validation of Sun photometer measurements, J. Geophys. Res., 102, 16,959-16,969, doi:10.1029/96JD02598.

Moulin, C., et al. (1998), Satellite climatology of African dust transport in the Mediterranean atmosphere, J. Geophys. Res., 103, 13,137-13,144, doi:10.1029/98JD00171.

Müller, D., I. Mattis, U. Wandinger, A. Ansmann, D. Althausen, O. Dubovik, S. Eckhardt, and A. Stohl (2003), Saharan dust over a central European EARLINET-AERONET site: Combined observations with Raman lidar and Sun photometer, J. Geophys. Res., 108(D12), 4345, doi:10.1029/ 2002JD002918.

Müller, D., A. Ansmann, I. Mattis, M. Tesche, U. Wandinger, D. Althausen, and G. Pisani (2007), Aerosol-type-dependent lidar ratios observed with Raman lidar, J. Geophys. Res., 112, D16202, doi:10.1029/ 2006JD008292.

Murayama, T., H. Okamoto, N. Kaneyasu, H. Kamataki, and K. Miura (1999), Application of lidar depolarization measurement in the atmospheric boundary layer: Effects of dust and sea-salt particles, J. Geophys. Res., 104, 31,781-31,792, doi:10.1029/1999JD900503.

Nickovic, S., G. Kallos, A. Papadopoulos, and O. Kakaliagou (2001), A model for prediction of desert dust cycle in the atmosphere, J. Geophys. Res., 106, 18,113-18,129, doi:10.1029/2000JD900794.

Papayannis, A., D. Balis, V. Amiridis, G. Chourdakis, G. Tsaknakis, C. Zerefos, A. Castanho, S. Nickovic, S. Kazadzis, and J. Grabowski (2005), Measurements of Saharan dust aerosols over the Eastern Mediterranean using elastic backscatter-Raman lidar, spectrophotometric and satellite observations in the frame of the EARLINET project, Atmos. Chem. Phys., 5, 2065-2079.

Pappalardo, G., et al. (2004), Aerosol lidar intercomparison in the framework of the EARLINET project. 3. Raman lidar algorithm for aerosol extinction, backscatter and lidar ration, Appl. Opt., 43, 5370-5385, doi:10.1364/AO.43.005370.

Pérez, C., S. Nickovic, J. M. Baldasano, M. Sicard, F. Rocadenbosch, and V. E. Cachorro (2006a), A long Saharan dust event over the western Mediterranean: Lidar, Sun photometer observations, and regional dust modeling, J. Geophys. Res., 111, D15214, doi:10.1029/2005JD006579.

Pérez, C., S. Nickovic, G. Pejanovic, J. M. Baldasano, and E. Ozsoy (2006b), Interactive dust-radiation modeling: A step to improve weather forecasts, J. Geophys. Res., 111(D16), D16206, doi:10.1029/ 2005JD006717. 
Prospero, J. M. (1996), Saharan dust transport over the North Atlantic Ocean and the Mediterranean, in The Impact of Desert Dust Across the Mediterranean, edited by S. Guerzoni and R. Chester, pp. 133-151, Springer, New York.

Prospero, J. M., P. Ginoux, O. Torres, S. E. Nicholson, and T. Gill (2002), Environmental characterization of global sources of atmospheric soil dust identified with Nimbus 7 Total Ozone Mapping Spectrometer (TOMS) absorbing aerosol product, Rev. Geophys., 40(1), 1002, doi:10.1029/ 2000RG000095.

Querol, X., A. Alastuey, J. de la Rosa, A. Sanchez-de-la-Campa, F. Plana, and C. R. Ruiz (2002), Source apportionment analysis of atmospheric particulates in an industrialised urban site in southwestern Spain, Atmos. Environ., 36, 3113-3125, doi:10.1016/S1352-2310(02)00257-1.

Rodriguez, S., X. Querol, A. Alastuey, G. Kallos, and O. Kakaliagou (2001), Saharan dust contributions to $\mathrm{PM}_{10}$ and TSP levels in Southern and Eastern Spain, Atmos. Environ., 35, 2433-2447, doi:10.1016/S13522310(00)00496-9.

Sakai, T., et al. (2002), Case study of Raman lidar measurements of Asian dust events in 2000 and 2001 at Nagoya and Tsukuba, Japan, Atmos. Environ., 36, 5479-5489, doi:10.1016/S1352-2310(02)00664-7.

Sokolik, I. N., D. M. Winker, G. Bergametti, D. Gillette, G. Carmichael, Y. Kaufman, L. Gomes, L. Schütz, and J. E. Penner (2001), Introduction to special section: Outstanding problems in quantifying the radiative impacts of mineral dust, J. Geophys. Res., 106, 18,015-18,027, doi:10.1029/2000JD900498.

Stier, P., et al. (2005), The aerosol-climate model ECHAM5-HAM, Atmos Chem. Phys., 5, 1125-1156.

Stohl, A. (1998), Computation, accuracy and applications of trajectoriesA review and bibliography, Atmos. Environ., 32, 947-966, doi:10.1016 S1352-2310(97)00457-3.

Tegen, I., S. P. Harrison, K. E. Kohfeld, S. Engelstaedter, and M. Werner (2002), Emission of soil dust aerosol: Anthropogenic contribution and future changes, Geochim. Cosmochim. Acta, 66, suppl. 1, A766.

Vautard, R., B. Bessagnet, M. Chin, and L. Menut (2005), On the contribution of natural Aeolian sources to particulate matter concentrations in Europe: Testing hypotheses with a modeling approach, Atmos. Environ., 39, 3291-3303, doi:10.1016/j.atmosenv.2005.01.051.

Weitkamp, C. (2005), Lidar: Range-Resolved Optical Remote Sensing of the Atmosphere, Springer, New York.

Winker, D. M., J. Pelon, and M. P. McCormick (2002), The CALIPSO mission: Aerosol and cloud observations from space, in Laser Remote Sensing in Atmospheric and Earth Sciences, Proceedings of the 21st International Laser Radar Conference, edited by L. R. Bissonette, G. Roy, and G. Vallée, pp. 735-738, Def. R\&D Can.-Valcartier, ValBelair, Canada.

Winker, D. M., W. H. Hunt, and M. J. McGill (2007), Initial performance assessment of CALIOP, Geophys. Res. Lett., 34, L19803, doi:10.1029 2007GL030135.
Zängl, G., and M. Hornsteiner (2007), The exceptional Alpine south föhn event of 14-16 November 2002: A case study, Meteorol. Atmos. Phys., 98, 217-238, doi:10.1007/s00703-006-0257-9.

Zender, C. S. (2004), Quantifying mineral dust mass budgets: terminology, constraints, and current estimates, Eos Trans. $A G U, 85(48), 509-512$, doi:10.1029/2004EO480002.

V. Amiridis, Institute for Space Applications and Remote Sensing, National Observatory of Athens, GR-11810 Athens, Greece.

D. Balis, Laboratory of Atmospheric Physics, Aristotle University of Thessaloniki, GR-54124 Thessaloniki, Greece.

J. Bösenberg, Max-Planck-Institut für Meteorologie, D-20146 Hamburg, Germany.

A. Chaikovski, Institute of Physics, National Academy of Sciences of Belarus, Minsk BY-220072, Belarus.

F. De Tomasi, Physics Department, University of Lecce, I-73100 Lecce, Italy.

M. Gerding, Leibniz-Institut für Atmosphärenphysik, Universität Rostock, D-18225 Kühlungsborn, Germany.

I. Grigorov, Institute of Electronics, Bulgarian Academy of Sciences, 1113 Sofia, Bulgaria.

I. Mattis and D. Müller, Leibniz Institute for Tropospheric Research, D-04318 Leipzig, Germany.

V. Mitev, Centre Suisse d'Electronique et de Microtechnique SA, CH2002 Neuchâtel, Switzerland.

L. Mona, G. D'Amico, and G. Pappalardo, Istituto di Metodologie per 1'Analisi Ambientale-CNR, I-85050 Potenza, Italy.

S. Nickovic, World Meteorological Organization, CH-1211 Geneva 2, Switzerland.

A. Papayannis, R. E. Mamouri and G. Tsaknakis, Physics Department, National Technical University of Athens, GR-10682 Athens, Greece.

C. Pérez, Earth Sciences Division, Barcelona Supercomputing Centre, E-08034 Barcelona, Spain.

A. Pietruczuk, Institute of Geophysics, Polish Academy of Sciences, 01452 Warsaw, Poland.

G. Pisani, CNISM and Dipartimente di Scienze Fisiche, Università di Napoli Federico II, I-80138 Napoli, Italy.

F. Ravetta, Service d'Aéronomie-IPSL, Université Pierre et Marie Curie (UP6), F-75005 Paris, France.

V. Rizi, CETEMPS and Dipartimento di Fisica, Università Degli Studi L'Aquila, I-67100 L'Aquila, Italy.

M. Sicard, Remote Sensing Laboratory, Universitat Politecnica di Catalunya, E-08034 Barcelona, Spain.

T. Trick1, Forschungszentrum Karlsruhe, IMK-IFU, D-82467 GarmischPartenkirchen, Germany.

M. Wiegner, Meteorologisches Institut, Universität München, D-80333 Munich, Germany. 